
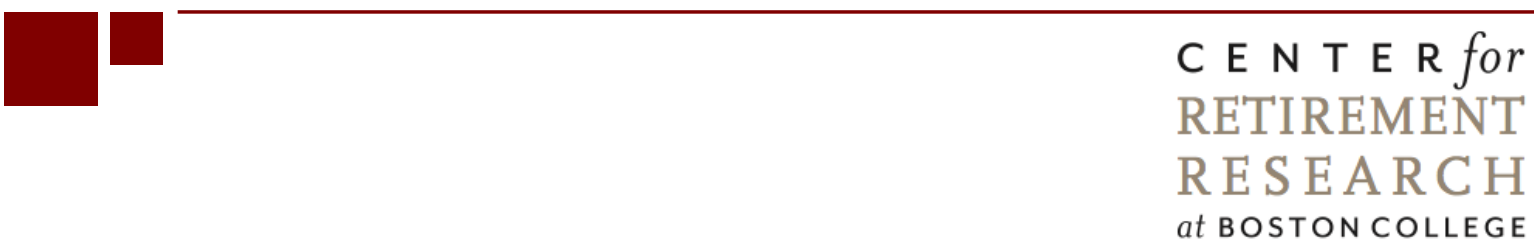

\title{
WHAT ARE THE EFFECTS OF DOUBLING UP ON RETIREMENT INCOME AND ASSETS?
}

\author{
Deirdre Pfeiffer, Katrin B. Anacker, and Brooks Louton
}

CRR WP 2016-10

September 2016

\author{
Center for Retirement Research at Boston College \\ Hovey House \\ 140 Commonwealth Avenue \\ Chestnut Hill, MA 02467
}

Tel: 617-552-1762 Fax: 617-552-0191

http://crr.bc.edu

Deirdre Pfeiffer is an assistant professor of planning at Arizona State University. Katrin B. Anacker is an associate professor of public policy at George Mason University. Brooks Louton is a Ph.D. candidate in criminology and criminal justice at Arizona State University. The research reported herein was pursuant to a grant from the U.S. Social Security Administration (SSA) funded as part of the Retirement Research Consortium (RRC). The findings and conclusions expressed are solely those of the authors and do not represent the views of SSA, any agency of the federal government, Arizona State University, George Mason University, or Boston College. Neither the United States Government nor any agency thereof, nor any of their employees, makes any warranty, express or implied, or assumes any legal liability or responsibility for the accuracy, completeness, or usefulness of the contents of this report. Reference herein to any specific commercial product, process or service by trade name, trademark, manufacturer, or otherwise does not necessarily constitute or imply endorsement, recommendation or favoring by the United States Government or any agency thereof.

(C) 2016, Deirdre Pfeiffer, Katrin B. Anacker, and Brooks Louton. All rights reserved. Short sections of text, not to exceed two paragraphs, may be quoted without explicit permission provided that full credit, including (C) notice, is given to the source. 


\title{
About the Steven H. Sandell Grant Program
}

This paper received funding from the Steven H. Sandell Grant Program for Junior Scholars in Retirement Research. Established in 1999, the Sandell program's purpose is to promote research on retirement issues by scholars in a wide variety of disciplines, including actuarial science, demography, economics, finance, gerontology, political science, psychology, public administration, public policy, sociology, social work, and statistics. The program is funded through a grant from the Social Security Administration (SSA). For more information on the Sandell program, please visit our website at: http://crr.bc.edu/?p=9570, send e-mail to crr@bc.edu, or call (617) 552-1762.

\section{About the Center for Retirement Research}

The Center for Retirement Research at Boston College, part of a consortium that includes parallel centers at the University of Michigan and the National Bureau of Economic Research, was established in 1998 through a grant from the Social Security Administration. The Center's mission is to produce first-class research and forge a strong link between the academic community and decision-makers in the public and private sectors around an issue of critical importance to the nation's future. To achieve this mission, the Center sponsors a wide variety of research projects, transmits new findings to a broad audience, trains new scholars, and broadens access to valuable data sources.

\author{
Center for Retirement Research at Boston College \\ Hovey House \\ 140 Commonwealth Ave \\ Chestnut Hill, MA 02467 \\ Tel: 617-552-1762 Fax: 617-552-0191 \\ http://crr.bc.edu
}

Affiliated Institutions:

The Brookings Institution

Syracuse University

Urban Institute 


\begin{abstract}
The Great Recession has amplified the increase in socioeconomic instability and inequality in the United States. While much work has been conducted on retirement income and assets, not much work has been undertaken on seniors moving in with their adult children and grandchildren, possibly to save on housing costs. Utilizing Survey of Income and Program Participation (SIPP) 1996, 2001, 2004, and 2008 data for seniors 65 and older, we conducted descriptive statistics and three types of models. First, we used discrete-time event history modeling to analyze the effect of changes in retirement income, assets, debt, and social welfare program participation between the current and previous interview on the propensity of moving into a multigenerational household, controlling for other factors. Then, we used logistic and linear regression to understand the effect of living in a multigenerational household on changes in seniors' retirement income, assets, debt, and program participation, controlling for other factors. We also expanded our analyses to control for household type, i.e., a senior moving in with adult children or grandchildren or vice versa, and for time, i.e., whether the recession impacts our results.
\end{abstract}

The paper found that:

- Experiencing economic distress increased the odds that a senior would move into a multigenerational household over the previous year or previous four months.

- Seniors living in multigenerational households were more economically disadvantaged than seniors not living in multigenerational households.

- Seniors living in multigenerational households were more likely to enroll in a social welfare program over the past four months than seniors not living in multigenerational households.

- The relationships between seniors' multigenerational household formation and economic outcomes did not change much during the recession.

The policy implications of the findings are:

- Living in a multigenerational household may have a potentially destabilizing effect on seniors' economic well-being. 
- Policymakers may want to target financial education and counseling to seniors living in multigenerational households. 


\section{Introduction}

Economic inequality has grown in the wake of the recent Great Recession. Much of the focus has centered on economic divides among racial and ethnic groups and between younger and older generations (Dunifon, Ziol-Guest, and Kopko, 2014; Elliott, Young, and Dye, 2011; Kochhar, Fry, and Rohal 2015; Mykyta and Maccartney, 2011). However, seniors, defined as people age 65 and older, were also hard hit (Hayutin 2012; Thayer 2007; Lusardi and Mitchell 2013; Butrica 2013). When the stock market bottomed out in the first quarter of 2009, retirement accounts had lost about \$2.7 trillion, i.e., 31 percent, and IRA accounts had declined 37 percent from their peak 2007 value (Butrica 2013). The unemployment rate among senior workers reached 7 percent by July 2009, which was highest since the end of the Great Depression (Firman et al. 2009).

Living arrangements influence the well-being of seniors and their family and shape their reliance on formal and informal social support networks (Wilmoth, 2001). Seniors have diverse living situations, responsibilities, and needs. We do not have a clear understanding of how seniors' household types may affect their economic outcomes. Most seniors live alone or with their spouse or partner; a small proportion live in institutional settings, such as in assisted living facilities, or nursing homes. Yet, a growing proportion of seniors live with other adults (who may be their relatives) in multigenerational households (Kamo, 2000).

Our research focuses on understanding the economic benefits and burdens of multigenerational households for seniors. Multigenerational households have two or more related adults from different generations under one roof. Multigenerational households may be formed by parents moving in with their adult children or grandchildren or adult children or grandchildren moving in with their parents or grandparents (Aquilino, 1990; Takagi and Silverstein, 2011). Multigenerational living differs from coresidence, when two or more related adults live in two or more households under one roof, which is somewhat common in Germany, Austria, and Switzerland (Isengard and Szydlik, 2012). ${ }^{1}$

In the $19^{\text {th }}$ and early $20^{\text {th }}$ century seniors commonly lived in multigenerational households to make ends meet after retirement or the death of a spouse (Billings and Blee, 1990; Elman and Uhlenberg, 1995; Ruggles 2007). It was not feasible for many to live alone until the advent of

\footnotetext{
${ }^{1}$ Intergenerational co-residence is different from intergenerational solidarity. Not co-residing does not necessarily indicate the weakening of ties (Grundy, 2005).
} 
Social Security in 1935 (see Ruggles (2003) for an alternative opinion). However, following the postwar period, the incidence of living in a multigenerational household among seniors declined, as seniors and their adult children and grandchildren became more economically independent and housing types such as accessory dwelling units (ADUs) or guest homes enabling multiple generations to live in a single-family home on one lot were outlawed (Billings and Blee, 1990; Ruggles 2007; Liebig et al. 2006).

Over the past two or three decades the multigenerational household has made a comeback, as seen from the increase in the number of ADUs, second units, granny flats, guesthouses, backyard cottages, secondary living quarters, accessory cottages, or echo homes (Aquilino, 1990; Choi, 1997; Goldscheider and Bures, 2003; Goldscheider and Lawton, 1998; Grundy, 2000; Isengard and Szydlik, 2012; Kamo, 2000; Macunovich et al., 1995; Pfeiffer, 2015; Ruggles, 2003). Currently, about one in six Americans lives in a multigenerational household with at least two adults over age 25 under one roof - the highest rate since 1950, when about one in four Americans lived in a multigenerational household (Taylor et al. 2011; see also Kamo 2000). Seniors are more likely than people of all age groups to live multigenerationally (20 percent compared to 16 percent) (Taylor et al. 2011). In turn, the proportion of seniors living multigenerationally has increased by three percentage points since 1990 (Harrell et al. 2011; see also Kamo 2000). Seniors may live in multigenerational households as household heads, meaning their adult children or grandchildren moved in with them (also called downward household extension (Kamo 2000)), or not as household heads, meaning they moved in with their adult children or grandchildren (also called upward household extension (Kamo 2000)). ${ }^{2}$

We do not have a clear understanding of why living in multigenerational households has become more common among seniors, and how living in different household types has affected seniors' livelihood, particularly during the recent Great Recession (Dunifon, Ziol-Guest, and Kopko, 2014; Elliott, Young, and Dye, 2011; Mykyta and Maccartney, 2011, 2011). ${ }^{3}$ Multigenerational households may offer economic benefits to seniors if they allow for resource sharing, including lower cost housing per head (Billings and Blee, 1990; Cohen and Casper, 2002; Dunifon, Ziol-Guest, and Kopko, 2014; Mutchler and Burr, 1991; Van Hook and Glick,

\footnotetext{
${ }^{2}$ Horizontal household extension occurs when members of the same generation, for example siblings, share a household (Kamo 2000).

${ }^{3}$ See Waehrer and Crystal who focus on the impact of coresidence on economic well-being of elderly widows as an exception (1995).
} 
2007). However, multigenerational households may also impose economic costs on seniors if relatives do not contribute their fair share to household expenses, called the "burden of dependency” by some (Billings and Blee, 1990, p. 80). Multigenerational households may be established based on the need of one or more parties, showing a possibly complex interplay of exchanges, but also based on altruistic motives (Choi, 2003; Elman and Uhlenberg, 1995; Isengard and Szydlik, 2012; Kok and Mandemakers, 2010; Mutchler, 1992; Mutchler and Baker, 2009; Mutchler and Burr, 1991, 2003; Pilkauskas, 2012; Smits et al., 2010; Zimmer and Dayton, 2005).

Interestingly, little is known about the relationship between seniors' retirement funds and reliance on social welfare support and their multigenerational household formation and residency. In turn, we do not have a clear understanding of how different types of multigenerational households, i.e., whether the senior is a household head or not, may affect their economic outcomes.

Our research helps to answer these questions using about 17 years of data from the 1996 to 2008 panels of the Survey of Income and Program Participation (SIPP) - a nationally representative, longitudinal sample that widely reports information on economic well-being. We assessed the factors contributing to seniors living in multigenerational households and the associations between seniors' household types and economic outcomes. We used a combination of descriptive statistics and econometric modeling. Of particular interest was whether the Great Recession period exhibited distinct trends.

The report is structured as follows. First, we address expectations for the determinants of seniors forming multigenerational households and how living in a multigenerational household may affect seniors' economic well-being. Next, we introduce the SIPP and discuss the research methodology. The bulk of the report examines the factors associated with seniors forming multigenerational households and assesses how living in a multigenerational household affects seniors' assets, debt, retirement income, and social welfare program participation. Of particular interest are whether determinants or effects differ based on how the multigenerational household forms (seniors moving in with their adult children or grandchildren, or adult children or grandchildren moving in with seniors) and time period (before the recent Great Recession or not). We conclude by reviewing the key takeaways of the research and its implications for policy concerning seniors in the wake of the Great Recession. 


\section{Determinants of Multigenerational Household Formation}

Factors that impact multigenerational household formation fall into four groups: first, macroeconomic factors; second, socioeconomic factors; third, demographic factors; and fourth, cultural factors. We explore each of these in this section.

\section{Factor Group \#1: Macroeconomic Factors}

Macroeconomic changes may have contributed to the resurgence in multigenerational living at the turn of the 21st century (Bureau of Labor Statistics 2014; Dunifon, Ziol-Guest, and Kopko, 2014; Elliott et al., 2011; Firman et al. 2009; Hayutin 2012; Mykyta and Macartney, 2011; Taylor et al. 2009; Thayer 2007; Lusardi and Mitchell 2013; Butrica 2013). Due to the national foreclosure crisis and the Great Recession, vacancy rates have decreased while nominal, median, average, and real rents have increased since 2010, making housing affordability for low, very low-, and extremely low-income renters a policy concern. Co-residence may be advantageous to all parties when there is sufficient space yet disadvantageous when there is insufficient space (Burr and Mutchler, 1992; Grundy, 2000; Isengard and Szydlik, 2012; Joint Center for Housing Studies of Harvard University, 2012, 2013; Mutchler and Burr, 2003; Smits et al., 2010).

\section{Factor Group \#2: Socioeconomic Factors}

One trend is the relatively high economic resources available to seniors today, including benefits disbursed by Social Security. These resources afford seniors privacy, independence, and institutionalized care; yet, these resources may also possibly contribute to loneliness and isolation (Choi, 1997; Chu et al., 2011; Frankenberg et al., 2011; Goldscheider and Bures, 2003; Gurak and Kritz, 2010; Isengard and Szydlik, 2012; Macunovich et al., 1995; Martin, 1989; Messineo, 2005; Mutchler, 1992; Mutchler and Burr, 1991; Ruggles, 2003; Smits et al., 2010; Takagi and Silverstein, 2011; Wolf and Soldo, 1988; Zsembik, 1993). Seniors can use these resources to support their adult children and grandchildren. For some, providing support may mean living together, which may also lead to seniors to be less isolated and lonely. ${ }^{4}$

\footnotetext{
${ }^{4}$ Indeed, the expectation of parental support predicts living at home (Messineo, 2005).
} 
Another trend is the increased inequality for disadvantaged households over the past four decades, including those with a senior resident, partly triggered by increasing housing and healthcare expenditures yet stagnant or real decreasing incomes for many (Kim and Waite, 2016; Taylor et al. 2011). Multigenerational households tend to form when related households have unequal economic resources (Angel and Tienda, 1982; Glick and Van Hook 2011; de Valk and Billari, 2007)). In turn, multigenerational households are more likely in cases of a lack of a high school degree and/or unemployment, especially after unemployment compensation, savings, and other sources of assistance have been exhausted (Choi, 1997, 2003; de Valk and Billari, 2007; Goldscheider and Bures, 2003; Isengard and Szydlik, 2012; Kim and Waite, 2016; Macunovich et al., 1995; Messineo, 2005; Mykyta and Macartney, 2011; Zsembik, 1993).

\section{Factor Group \#3: Demographic Factors}

Over the past three decades multigenerational households have become more prevalent (Aquilino, 1990; Choi, 1997) due to the increase in the number of years lived, which typically coincides with health-related issues (Choi, 1999b, 2003; Frankenberg et al., 2002; Grundy, 2000; Mutchler, 1992; Mutchler and Burr, 1991, 2003; Pilkauskas, 2012; Zsembik, 1993). They have also become somewhat more common due to the increase in the overlap of the number of shared years lived between and among generations (Ruggles, 2003, 2007). Moreover, there is the availability, number, and hierarchy of kin, i.e., single, divorced, or widowed childless younger adult females have higher odds of coresidence, followed by single, especially teenage, mothers (Aquilino, 1990; Bengtson, 2001; Burr and Mutchler, 1992; Choi, 1997, 1999a, 2003; Elman and Uhlenberg, 1995; Goldscheider and Bures, 2003; Grundy, 2000; Isengard and Szydlik, 2012; Kok and Mandemakers, 2010; Macunovich et al., 1995; Martin, 1989; Messineo, 2005; Mutchler, 1992; Mutchler and Burr, 1991; Pilkauskas, 2012; Smits et al., 2010; Wilmoth, 2001; Wolf and Soldo, 1988; Zsembik, 1993; see also Chu et al. (2011) for the Chinese and Taiwanese traditions). Older seniors are more likely to live in an upwardly extended household as they tend to have a deteriorating health, emerging chronic illness or disability, and/or functional dependence (Burr and Mutchler, 1992; Choi, 1997, 1999a, 1999b; Dunifon, Ziol-Guest, and Kopko, 2014; Elman and Uhlenberg, 1995; Gonzales, 2007; Kamo 2000; Macunovich et al., 1995; Messineo, 2005; Mutchler and Burr, 1991, 2003; Smits et al., 2010; Takagi and Silverstein 2011; Wolf and Soldo, 1988; Zsembik, 1993; see also Ruggles (2003) for an alternative opinion). 
Older females are more likely to be a host while younger males are more likely to be the guest in a multigenerational household (called the "feathered nest hypothesis" in the latter case) (Cohen and Casper, 2002; Isengard and Szydlik, 2012; Smits et al., 2010).

\section{Factor Group \#4: Cultural Factors}

Intergenerational solidarity has grown stronger and more resilient over the past four decades, as the importance of grandparents and other relatives in fulfilling family functions has increased. The increased workforce participation of women, along with high rates of cohabitation, marital instability, divorce, and widowhood, elevate the role of grandparents and other relatives in fulfilling family functions (Aquilino, 1990; Bengtson, 2001; Choi, 1997, 1999a, 1999b; Cohen and Casper, 2002: Goldscheider and Lawton, 2014; Isengard and Szydlik, 2012; Martin, 1989; Messineo, 2005; Mutchler, 1992; Smits et al., 2010; Van Hook and Glick, 2007; Wolf and Soldo, 1988). Obligations toward kin as well as filial obligations have become more prominent in this climate (Kim and Waite, 2016).

African Americans, Latinos, and Asians are more likely to be in multifamily households (Choi, 1997, 1999a, 1999b, 2003; Cohen and Casper, 2002; Dunifon, Ziol-Guest, and Kopko, 2014; Goldscheider and Bures, 2003; Gurak and Kritz, 2010; Morgan et al., 1993; Mutchler and Burr, 2003; Van Hook and Glick, 2007; see also Aquilino (1990) for an alternative opinion). African Americans, compared to other races and ethnicities, tend to live in downwardly extended households due to their 1) fewer economic resources yet higher needs, 2) higher rates of single mothers, 3) higher teenage pregnancy rates, 4) higher rates of disability, and 5) higher degree of household complexity compared to other races and ethnicities, possibly mirroring norms in North African countries (Angel and Tienda, 1982; Choi, 1999b; Goldscheider and Bures, 2003; Mutchler, 1992; Wolf and Soldo, 1988; Zimmer and Dayton, 2005). Many African Americans also tend to head households containing only grandchildren (Choi, 1999a; Morgan et al., 1993; Mutchler and Baker, 2009; Zimmer and Dayton, 2005). Also, some African Americans appear to be willing to combine resources of several generations, particularly during recessions, due to the history of slavery, economic hardship, and relatively strong intergenerational support (Choi, 1999a, 2003; Dunifon, Ziol-Guest, and Kopko, 2014; Cohen and Casper, 2002; Goldscheider and Bures, 2003; Kamo, 2000; Mutchler and Baker, 2009; Pilkauskas, 2012). By living in 
multigenerational households, many senior African Americans are able to avoid expensive institutionalized care (Choi, 1999b)

Latinos, compared to other races and ethnicities, tend to live in either downwardly or horizontally extended households due to their 1) fewer resources yet higher needs, 2) focus on families and filial obligations, 3) preference for informal care arrangements over institutionalized care, 4) language barriers and degree of acculturation, 5) recent immigration and the five-year waiting period for access to welfare benefits, 6) relatively high proportion of immigrants with an uncertain migration status, or 7) possibly mirroring norms in Spain (or Southern Europe), which has a relatively high proportion of multigenerational households (Angel and Tienda, 1982; Burr and Mutchler, 1992; Burr et al., 2013; Choi, 1997, 1999a, 1999b, 2003; Elman and Uhlenberg, 1995; Gonzales, 2007; Gurak and Kritz, 2010; Isengard and Szydlik, 2012; Kamo 2000; Mykyta and Macartney, 2011; Mutchler and Burr, 2003; Pilkauskas, 2012; Van Hook and Glick, 2007; Wilmoth, 2001; Zsembik, 1993; see also Aquilino (1990) for an alternative opinion).

Asians, compared to other races and ethnicities, tend to live in upwardly extended households due to their 1) tradition of filial responsibility, especially along the male line, derived from Confucianism, Buddhism, or Islamism (i.e., absolute love and respect for one's parents and ancestors), 2) language barriers, and 3) fewer resources yet higher needs among some subgroups (Choi, 1999a, 2003; Chu et al., 2011; Frankenberg et al., 2002; Kamo 2000; Martin, 1989; Mutchler and Burr, 2003; Takagi and Silverstein, 2011; Wilmoth, 2001).

\section{Multigenerational Household Formation and Economic Outcomes}

Multigenerational households may serve as a mutually beneficial arrangement with benefits as well as burdens for all parties. They may also provide a system of old-age support (Ruggles, 2003).

\section{Economic Benefits of Multigenerational Living for Seniors}

There is growing consensus on many economic benefits that seniors and their adult children and grandchildren derive from living in a multigenerational household. Living together may be less expensive than living apart. By sharing a home, seniors and their adult children and grandchildren are able to pool their incomes while splitting monthly housing and other costs, or provide services, such as childcare or food preparation, in lieu of payment (Bethell 2011; Choi, 
1999a; Chu et al., 2011; Cohen and Casper, 2002; Mutchler and Baker, 2009; Ruggles, 2003). This arrangement may protect household members from poverty and leave them with more money left to pay for other expenses (Bethell 2011; Mutchler and Baker, 2012). Living multigenerationally may enable adolescent mothers to further or complete their education, search for and secure employment, fulfill their own developmental needs, become more competent in their parenting, and expose their children to higher quality childcare (Oberlander et al., 2009). Living multigenerationally also may enable seniors' adult children and grandchildren to better weather income fluctuation, especially if they can rely on their parents’ or grandparents' fixed income to make ends meet.

People living in multigenerational households tend to have a lower incidence of poverty than those in other living arrangements (11.5 percent compared to 14.6 percent in 2009). This trend is particularly pronounced among older seniors, age 85 and older. Older seniors living in multigenerational households had a poverty rate of 5.7 percent in 2009 compared to 13.9 percent for older seniors in other living arrangements. Although multigenerational households have lower incomes, they also have more income sharing among members. Household heads living in multigenerational households accounted for 48.8 percent of total household income in 2009 compared to 85.7 percent for household heads in other living arrangements. Many Americans consider forming a multigenerational household a "financial lifeline" translating into an "antipoverty program” (Taylor et al. 2011, p. 1).

\section{Economic Burdens of Multigenerational Living for Seniors}

Multigenerational households also may impose economic and social costs on residents. When unemployment and other conditions prompt adult children or grandchildren to move in with seniors, seniors' expenses may increase if their adult children or grandchildren lack the ability to contribute economically to the household. In turn, living with their adult children may lead seniors to be more aware of their economic hardships, such as paying off student loans or a mortgage. As a result, seniors may incur extra expenses in meeting their adult children's needs. In case of adolescent mothers, multigenerational households may strain relationships due to conflicts centered around childcare and discipline, and grandparental and parental stress (Oberlander et al., 2009). Also, some adult children may experience difficulties finding a partner due to their living situation (Smits et al., 2010). 


\section{Gaps in Knowledge}

There are major gaps in knowledge on the relationships between multigenerational household formation and seniors' assets, debt, retirement income, and social welfare program participation that are ripe for addressing. Although there is growing research on the role that unemployment has played in the formation of multigenerational households, we know little about how fluctuations in assets, debt, and retirement income may be contributing to this trend. How multigenerational living arrangements affect seniors' receipt of Social Security and participation in social welfare programs is of particular interest. On the one hand, seniors in multigenerational households may be less likely to receive social welfare. If this is occurring, forming multigenerational households may help to stabilize these programs. On the other hand, living in a multigenerational household may prompt seniors to seek support from social welfare programs. This trend could be helping to destabilize these programs.

We do not have a clear picture of how the causes, benefits and costs of living in a multigenerational household are shaped by how the household forms. Declines in retirement income and assets and increases in debt may more drive seniors to move in with their adult children and grandchildren, while increases in retirement income and assets may more drive seniors' adult children and grandchildren to move in with them. Seniors who move in with their adult children and grandchildren may be better off economically over time, as their adult children and grandchildren may provide a social safety net. Seniors who have their adult children and grandchildren move in with them may be worse off economically over time, as their adult children and grandchildren may not contribute their fair share to household expenses and strain seniors' resources.

Finally, whether or not the relationships among doubling up, assets, debt, retirement income, and participation in social welfare programs changed during the Great Recession is an understudied question (Keene and Batson 2010). Relationships between multigenerational household formation and changes to assets, debt, retirement income, and social welfare program participation may have been weaker during the recession, given other forms of economic tumult that were occurring at the time (increases in housing costs and foreclosure, decreases in employment) that may have spurred a family to double up. 


\section{Data and Method}

\section{Research Questions}

This research seeks to deepen understanding of why seniors form multigenerational households and how living in them influences their assets, debt, retirement income, and participation in social welfare programs. In this report we answer the following five questions about these phenomena:

1) What factors are associated with seniors forming multigenerational households?

2) Do changes in assets, debt, retirement income, and participation in social welfare programs affect seniors' formation of multigenerational households, and if so, how?

3) Does doubling up affect seniors' assets, debt, retirement income, and participation in social welfare programs, and if so, how?

4) Do these relationships vary based on whether seniors moved in with their adult children or grandchildren or their adult children or grandchildren moved in with them, and if so, how?

5) Does the recession affect these relationships, and if so, how?

We expected to find that seniors who recently experienced declines in retirement income and assets, increases in debt, and enrollment in social welfare programs were more likely to form multigenerational households. We also expected to find that seniors who had their adult children and grandchildren move in with them experienced fewer economic benefits than those who moved in with their adult children and grandchildren. In particular, we expected these seniors to be more likely to experience declines in assets and retirement income and increases in debt and enroll in social welfare programs. Finally, we hypothesized that links between declines in retirement income and assets and increases in debt and forming a multigenerational household were weaker during the recession as compared to earlier years.

\section{Data}

We used the Survey of Income and Program Participation (SIPP) data to better understand the relationships among assets, debt, retirement income, and participation in social welfare programs, and multigenerational household formation among seniors. The SIPP, which started in 1983, is an ongoing, longitudinal survey conducted by the United States Bureau of the Census that captures information on current employment, income, and assets and liabilities as 
well as past addresses. The SIPP is open to U.S. residents ages fifteen and up who are not living in military barracks or institutionalized (incarcerated, hospitalized, or in nursing homes). The survey was intended to improve upon the Current Population Survey (CPS) to enable better understanding of the distribution of income, wealth, and poverty in the U.S., as well as the effects of state and federal programs aimed at improving wellbeing. Thus, SIPP oversamples households in areas with high poverty rates (Allen et al.1993). Each SIPP panel lasts from 2.5 to four years. Our study uses data from the 1996, 2001, 2004, and 2008 waves, the most recent available when we started this project.

The SIPP is comprised of a nationally representative sample of households. Interviews are conducted with all household members who are at least fifteen years old at the time of the interviews. Households are selected for the study by using a cluster sampling method, with lowincome areas oversampled in 1996. Primary sampling units (PSUs) are constructed from a list of counties and independent cities, with larger PSUs represented independently and smaller units grouped into strata within their states. All of the larger PSUs and a sample of smaller PSUs in each stratum are then sampled for households using five separate, non-overlapping address sample frames (U.S. Census Bureau, 2009). The initial number of sampled households was 40,188 in 1996, 50,500 in 2001, 51,379 in 2004, and 52,031 in 2008 (U.S. Census Bureau, 2009).

Sample members are interviewed once every four months (called waves) for the duration of the study, for a total of between nine and sixteen interviews per person for the waves under study. The owner or renter of record at each initial address in the wave is assigned as the household reference person, and all other household members are listed according to their relationship to the reference person. Household members that move out of the initial address are still included in the sample for the duration of the study, and new household members are added and remain in the study as long as they reside at the initial address.

Our sample was comprised of original respondents to the survey who were noninstitutionalized seniors age 65 and older. These criteria yielded a sample of about 10,700 to 13,700 seniors per panel for a total of about 49,000 seniors across the four panels (see Table 1).

We used Glick and Van Hook (2011)’s method to identify seniors living in multigenerational households. This entailed identifying the number of "minimal household units” (MHUs) within a household during each interview and whether they are related. Couples 
and parents with children or grandchildren who were younger than 25 (who did not have children and did not have a spouse or partner) were counted as one MHU. Parents with children or grandchildren who were younger than 25 who had a spouse or partner and/or children were counted as two MHUs. Adults age 25 and older were counted as one MHU. Multigenerational households were defined as those with 1) at least two MHUs and 2) at least one parent-child or parent-grandchild relationship between the MHUs. About 17 percent of seniors in each panel lived in multigenerational households (see Table 1).

The household status of most seniors stayed consistent from one year to the next (see Table 1). About 11 percent to 14 percent of seniors consistently lived in multigenerational households during each wave across the four panels. About 20 percent to 22 percent of seniors ever lived in a multigenerational household during a wave across the four panels. About 1 percent of seniors not living in multigenerational households at the start of the year were living in multigenerational households by the end of the year. About 1 percent of seniors living in multigenerational households at the start of the year were not living in multigenerational households by the end of the year.

We used information on whether the MHU containing the senior also contained the household reference person to determine how the multigenerational household formed (whether the parents moved in with their adult children or grandchildren, or vice versa). Seniors in MHUs containing the reference person had their adult children or grandchildren move in with them; those not in MHUs containing the reference person moved in with their adult children or grandchildren. Most seniors living in multigenerational households (68 percent) were the household reference person, henceforth called the household head (see Table 1). Seniors who were household heads in multigenerational and non-multigenerational households at the start of the year tended to remain household heads by the end of the year. This same trend was evident for seniors who were not household heads at the start of the year.

There are two types of questions in the SIPP data: first, core coverage questions asked at every interview; and second, topical coverage questions that are not asked at every interview and that may vary across waves. Core coverage questions are typically asked on a monthly basis, although, where appropriate, they may be asked only as of the interview date. The core coverage questions include information on demographic characteristics, labor force participation, program participation, amounts and types of earned and unearned income received, including transfer 
payments, noncash benefits from various programs, asset ownership, private health insurance, employment and earnings, program, general, and asset income, health insurance ownership and coverage, education, and energy assistance, and school lunch program participation, among other topics.

Topical coverage questions provide additional details about social and economic characteristics, as well as personal histories. The reference period for topical questions can vary from only recent events to the entire life course. While some topical questions are asked at multiple waves, not all are. These questions tend to evolve more quickly than the core coverage questions as new issues arise. For example, questions about welfare reform are included in the most recent available data, although not in all previous waves. Among the topics for these questions are assets and liabilities, school enrollment, marital history, fertility, migration, disability, and work history. For our study, we are particularly interested in participants' assets and liabilities that affect retirement.

We accounted for changes in a variety of assets, debt, retirement income, and social welfare programs as dependent and explanatory variables in the analyses. Assets included government or corporate bonds, life insurance plans, IRA, KEOGH, and 401K pension plans, checking, savings, and money market accounts, mutual funds, stocks, residences, rental properties, and cars, among other sources. Debt included outstanding balances of credit cards and mortgage and car loans, among other sources. Retirement income included monthly distributions from IRAs, KEOGHs, and 401ks and other pension plans and Social Security, among other sources. We also accounted for whether or not the senior was receiving other social welfare benefits, such as Medicaid, Supplementary Security Income, veterans' payments, food stamps, and subsidized housing, among other sources.

We constructed composite variables to analyze changes to seniors' net worth (assets minus debt), total monthly retirement income, and enrollment in any social welfare program. Only a fraction of the vast assets, debt, retirement income, and program participation variables included in the SIPP were disaggregated in the analysis, because few of the respondents reported having many of these variables. Sources that were reported by close to or over 10 percent of seniors in the first core or topical wave of each panel were analyzed separately. These sources are listed on Table 2. We accounted for annual changes in assets and debt, since questions on these indicators were only asked during the topical waves (typically once a year for the duration 
of the panel). We accounted for changes in retirement income and social welfare program participation three times a year, since questions on these indicators were asked during the core waves.

We examined a series of fixed and time varying control variables that were measured in each panel year and associated with doubling up and fluctuations in assets, debt, retirement income, and participation in social welfare programs. Fixed control variables included the senior's race and ethnicity and sex. Time varying variables included age, educational attainment, marital status, income, health status, tenure, household size, and the panel year and wave. Virtually none of the participants had missing information for these variables. We also accounted for changes in all but the temporal time-varying variables between the current and previous interview when possible. We examined pairwise correlations among the control variables prior to modeling and included only one of pairs that were strongly correlated in the models.

\section{Method}

We arranged the data into a longitudinal file that had an observation for each time a senior respondent was interviewed (once a year for assets, debt, and health status, and three times a year for all other variables, over the years seniors were in the sample). We included separate variables indicating whether seniors' households became multigenerational in between the current and previous interview, and if so, whether the household formed by them moving in with their adult children or grandchildren or their adult children or grandchildren moving in with them. Each observation also contained information about changes in assets, debt, retirement income, and participation in social welfare programs, as compared to the previous year or previous four months (excluding the first observation). We only included observations from waves shared across the panels. Overall, our analysis included about 340,000 observations split across the four panels and nine waves within each panel (see Table 1).

Initially, we conducted basic descriptive statistics, such as means and standard deviations, cross tabulations, and t-tests of differences in means and proportions to better understand the magnitude and significance of relationships among changes in assets, debt, retirement income, participation in social welfare programs, and doubling up. 
Next, we examined the independent associations among these factors and outcomes using econometric modeling. We used the survey regression function (svy) in Stata to account for the clustering within the samples and respondents and to generate population estimates using sample weights. First, we used discrete-time event history modeling to understand the effect of changes in assets, debt, retirement income, and program participation between the current and previous interview on the propensity of moving into a multigenerational household over the year while controlling for other contributing factors described above. This specification handles right-hand truncation and enables the analysis of seniors that have been in the sample for different lengths of time. Once a senior formed a multigenerational household, they were not included in subsequent periods unless the household disbanded, as they were no longer "at-risk" of forming one. The model specification was as follows,

n

$$
\begin{gathered}
\text { 1. } \ln (\text { Mit/1-Mit })=a+b(\text { Ait-Ait-1 })+c(\text { Fit })+d(\text { Vit })+\sum \text { tiTi } \\
i=0
\end{gathered}
$$

where:

- M was whether or not the senior moved into a multigenerational household between the current and previous interview;

- A were the changes in various assets, debt, retirement income, and social welfare program enrollment over this period, which were modeled separately;

- $\quad \mathrm{F}$ and $\mathrm{V}$ were the fixed and time-varying control variables; and

- Ti were the dummy variables for the number of time periods in the sample, with period zero (the second interview) as the excluded category.

Second, we used linear and logistic regression to understand the effect of living in a multigenerational household on whether seniors experienced changes in their assets and debt and withdrew various sources of retirement income or participated in various social welfare programs, including the same fixed and time varying controls. The model specification was as follows,

$$
\text { 2. Ait or } \ln (\text { Wit/1-Wit })=a+b(\text { Mit })+c(\text { Fit })+d(\text { Vit })
$$

where: 
- A was the value of an asset, debt, or retirement income and $\mathrm{W}$ was whether the senior was enrolled in a social welfare program;

- M was whether or not the senior was living in a multigenerational household in at least the current and previous interview period; and

- $\quad \mathrm{F}$ and $\mathrm{V}$ were the fixed and time-varying control variables.

We ran separate models for each asset, debt, retirement income, and social welfare program to understand the effects of living in a multigenerational household on these sources in time and over time.

In the second iteration of the models, we accounted for whether the multigenerational household was formed by a senior moving in with their adult children or grandchildren or their adult children or grandchildren moving in with them. In models 1 and 2 above, the variable representing whether or not the senior lives in a multigenerational household was reconstructed to a variable representing whether or not the senior lived in a multigenerational household formed by moving in with one's adult children or grandchildren or having one's adult children or grandchildren move in with them. Another iteration assessed differences between seniors living in multigenerational and non-multigenerational households among household heads and nonhousehold heads, respectively.

In the third iteration of the models, we examined whether the relationships described above changed during the recession (Elliott, Young, and Dye, 2011; Mykyta and Macartney, 2011). To test for this potential change, we interacted the variables accounting for the panel year with the primary explanatory variables (changes in assets, debt, retirement income, program participation, and living in a multigenerational household) to assess whether there was an effect.

\section{Limitations}

The SIPP, like other national longitudinal surveys, is subject to several sources of potential error, which may lead to biases. First, the SIPP sample is not a simple random sample. Thus, users must take care to weight the data properly and, in particular, to account for oversampling of low-income households in the data. Second, the Census Bureau imputes data in order to create full panel files where data is missing, most often using a "hot deck" technique, in which non-response items are filled in with answers from households with similar characteristics (U.S. Census Bureau, 2009). While this enables analysis of a larger sample size, it is possible 
that the imputed data is not representative of the missing data, causing biased estimates. Other sources of potential bias include the possibility for households to fail to report all members and some undercoverage of demographic subgroups (e.g., African American males), as well as the sample attrition common to all longitudinal surveys. Additionally, the data may be subject to non-response biases and response errors, particularly recall errors in which respondents have difficulty separating out events over the time period in question. Third, the SIPP has relatively high attrition rates. About 20 percent of the original sample typically drops out during the course of the study period; about half of all attribution occurs between the first and second interviews (Van Hook and Glick, 2007)

Despite these issues, the SIPP is a useful source for the questions under study. We were careful to weight the data appropriately and took steps to reduce bias as much as possible. We conducted various robustness checks to identify and remedy threats to internal validity.

\section{Results: The Economic Benefits and Burdens of Multigenerational Households for Seniors}

This section provides insight into the determinants of seniors' multigenerational household formation and the economic benefits and burdens experienced by seniors living in multigenerational households. First, we describe the factors associated with seniors living in and forming multigenerational households. Of particular interest are how changes in seniors' assets, debt, retirement income, and social welfare program participation affect their multigenerational household formation. Next, we compare the economic conditions of seniors living and not living in different types of multigenerational households. Finally, we address whether living in a multigenerational household affects seniors' economic outcomes.

\section{Determinants of Seniors’ Multigenerational Household Formation}

The demographic and socioeconomic characteristics of seniors living in multigenerational households differed distinctly from the demographic and socioeconomic characteristics of seniors not living in multigenerational households (see Table 3). These differences largely persisted across the panel years. Seniors who lived in multigenerational households were more likely to:

- Live in urban areas (83 percent vs. 77 percent); 
- Be Latino (13 percent vs. 4 percent), Asian (6 percent vs. 2 percent), and African American (14 percent vs. 7 percent);

- Be female (64 percent vs. 57 percent), widowed (47 percent vs. 30 percent), and live in larger households (3.3 members vs. 1.6 members); and

- Lack a high school degree (38 percent vs. 24 percent) and earn less monthly income on average ( $\$ 1,819$ vs. $\$ 2,322)$.

Seniors who lived in multigenerational households were less likely to:

- Report being in good health (59 percent vs. 69 percent); and

- Own a home (56 percent vs. 75 percent).

Seniors who lived in multigenerational households also were more likely to have experienced positive or negative changes to their health and movement into or out of homeownership over the year. Many of these reported demographic and socioeconomic differences between seniors living and not living in multigenerational households are consistent with the literature (Elliott, Young, and Dye, 2011; Kamo, 2000; Mykyta and Macartney, 2011).

Seniors living in multigenerational households of different types also had divergent demographic and socioeconomic characteristics (see Table 3). These differences persisted across the panel years, as with differences between seniors living and not living in multigenerational households, consistent with the literature (Elliott, Young, and Dye, 2011; Mykyta and Macartney, 2011). Seniors living in multigenerational household who were not household heads (i.e., they moved in with their adult children or grandchildren) were more likely to:

- Live in urban areas (86 percent vs. 81 percent);

- Be Latino (18 percent vs. 11 percent) and Asian (12 percent vs. 4 percent);

- Be age 85 and older (15 percent vs. 6 percent), female (71 percent vs. 60 percent), widowed (63 percent vs. 38 percent), and live in larger households (3.8 members vs. 3.1 members); and

- Lack a high school degree (45 percent vs. 34 percent) and earn less monthly income on average (\$1,382 vs. \$2,051).

Seniors living in multigenerational household who were not household heads were less likely to:

- Report being in good health (51 percent vs. 63 percent); and

- Own a home (11 percent vs. 80 percent) and live in a home that is owned (81 percent vs. 87 percent). 
Seniors who were living in multigenerational households not as household heads also were more likely to have recently transitioned out of homeownership (6 percent vs. 3 percent) and experienced both positive and negative changes to their health over the past year.

Most of the differences between seniors who were living in multigenerational households and not were still present when only examining seniors who were household heads or not household heads. Differences between seniors who were living in multigenerational households and not as non-household heads were similar in some ways (though larger) but different in other ways. For instance, seniors who were not household heads living in multigenerational households were more likely to be Latino (18 percent vs. 8 percent), widowed (63 percent vs. 34 percent), and of lower socioeconomic status (average monthly income of \$1,382 vs. \$1,863 and 45 percent vs. 35 percent lacking a high school degree), like seniors who were household heads in multigenerational households. These seniors also were less likely to report being in good health (51 percent vs. 61 percent) and more likely to report experiencing improved health over the year (14 percent vs. 11 percent), like seniors who were household heads in multigenerational households.

However, seniors who were not household heads in multigenerational households were much more likely to be Asian (12 percent vs. 3 percent), female (71 percent vs. 53 percent), and age 85 and older (15 percent vs. 7 percent) and no more likely to be African American (10 percent vs. 11 percent), unlike seniors who were household heads in multigenerational households. These seniors also were less likely to be divorced or separated (12 percent vs. 33 percent) or single (5 percent vs. 28 percent), compared to seniors who were not household heads and not living in multigenerational households.

Controlling for seniors' demographic and socioeconomic characteristics though regression modeling helped to illuminate which of the differences above most defined seniors living multigenerational households (see Table 4). Being a person of color was strongly associated with living in a multigenerational household, controlling for other characteristics. Compared to non-Hispanic Whites, henceforth called "Whites," the odds of living in a multigenerational household were highest for seniors who were Asian (5.056), followed by Latino (3.486) and African American (2.137). Being widowed and not having attended at least some college were also associated with increased odds of living in a multigenerational household. Sex did not affect seniors’ odds of living in a multigenerational household; being 
older was associated with lower odds of living in a multigenerational household, although this effect was only marginally statistically significant.

Race, ethnicity, marital status, and education were useful in predicting whether a senior living in a multigenerational household was a household head or not (see Table 4). Seniors who were Latino or Asian were more likely to be non-household heads (living with their adult children or grandchildren) than seniors who were White (odds ratios of 2.021 and 4.528 respectively). Seniors who were widowed, older, and had not attended at least some college were also more likely to be non-household heads. However, seniors who were African American were less likely to be non-household heads than seniors who were White (odds ratio of 0.681).

Race, ethnicity, marital status, and education also helped to predict whether a senior of a particular household head status was living in a multigenerational household (see Table 4). Being a person of color increased the odds of living in a multigenerational household, among seniors who were household heads (odds ratios of 2.404 to 2.816). Seniors who were Latino or Asian also had higher odds of living in a multigenerational household compared to seniors who were White among those who were not household heads (odds ratios of 3.346 and 6.684); being African American did not increase seniors' odds of living in a multigenerational household compared to being White among those who were not household heads. Among seniors who were household heads and not, being widowed and less educated increased the odds of living in a multigenerational household. Increases in age decreased the odds of living in a multigenerational household among seniors who were household heads but increased the odds of living in a multigenerational household among seniors who were not household heads. In turn, female seniors who were not a household head were more likely to live in a multigenerational household. Seniors who were female and household heads were less likely to live in a multigenerational household, though this effect was only marginally statistically significant.

We found two temporal effects in this analysis. First, seniors interviewed during the 1996 and 2001 panels were less likely to report living in a multigenerational household compared to seniors interviewed in the 2008 panel. Second, among seniors who were living not as household heads, those who were interviewed in the 1996 panel were less likely to report being in a multigenerational household compared to those interviewed in the 2008 panel. These findings are consistent with evidence that the proportion of seniors living in multigenerational households has increased over time (Taylor et al. 2011). 
Examining only the topical wave observations (i.e., taken once a year) reveals several additional factors associated with the odds of a senior living in a multigenerational household (see right hand columns of Table 4 above). Seniors who were homeowners and reported being in good health were less likely to live in a multigenerational household (odds ratios of 0.611 and 0.825, respectively). These seniors were also less likely to be living with their adult children or grandchildren, among those living in multigenerational households. Seniors who reported being in good health were less likely to live in multigenerational households, controlling for household head status. Among household heads, seniors who were homeowners were more likely to live in multigenerational households (odds ratio of 1.701). In contrast, among non-household heads, seniors who were homeowners were less likely to live in multigenerational households (odds ratio of 0.610$)$.

We next examined how changes in seniors' life circumstances affected their propensity of moving into a multigenerational household over the year, controlling for demographic and socioeconomic characteristics associated with multigenerational living. We used the topical wave observations to examine these dynamics (see Table 5).

Becoming widowed and transitioning out of homeownership, either through selling the home or foreclosure, strongly increased the odds of moving into a multigenerational household by the end of the year (odds ratios of 2.667 and 5.115 respectively) (see Table 5). Seniors who became a homeowner were not more likely to form a multigenerational household. Seniors who became widowed were more likely to move in with their adult children or grandchildren and have their adult children or grandchildren move in with them compared to seniors who did not become widowed (odds ratios of 3.610 and 2.285) (see Tables 5). Seniors who transitioned out of homeownership were much more likely to move in with their adult children or grandchildren compared to seniors whose tenure remained stable over the year (odds ratio of 24.160). Experiencing changes in health or monthly income were not associated with moving into a multigenerational household. In turn, there was no observable temporal effect on whether or not a senior moved into a multigenerational household over the year. 
How Changes in Assets, Debt, Retirement Income, and Social Welfare Program Participation Affect Seniors' Multigenerational Household Formation

Seniors were more likely to form multigenerational households when they were facing financial stress, meaning they lost assets or income or enrolled in a social welfare program over the previous the year or previous four months. Tables 6-8 report these effects, controlling for seniors' demographic and socioeconomic characteristics, the wave and panel year, and changes in senior's marital status, health, tenure, and personal monthly income over the year or past four months. Effects are reported for composite variables, such as net worth, total monthly retirement income, and receipt of any social welfare program, and disaggregated sources received by at least 10 percent of seniors in the panel. Monetary values are reported in raw and logged form, due to the extreme left or negative skew of many of the sources. The likelihood of a senior having lost the value of a monetary source is also reported.

Seniors who lost net worth over the year were more likely to move in with their adult children or grandchildren compared to seniors who experienced growth or no change in their net worth (odds ratio of 2.174). Losing home equity, life insurance assets, social security income, and enrolling in a social welfare program (including and excluding Medicare) were associated with seniors having their adult children or grandchildren move in with them (odds ratios of $1.289,1.237,1.336$, and 1.907/1.534 respectively). However, the effects of losing home equity and enrolling in a social welfare program were only marginally significant (10 percent level). Seniors who lost pension income were more likely to form multigenerational households, either by moving in with their adult children or grandchildren or having their adult children or grandchildren move in with them (odds ratios of 1.807 and 1.350 respectively).

For one source, regaining financial footing was associated with seniors forming multigenerational households — credit card debt. Seniors who reduced their credit card debt over the year were more likely to have their adult children and grandchildren move in with them (odds ratio of 1.545). However, increases in seniors' other assets and incomes, such as the value of their interest-bearing accounts and stocks, were associated with lower likelihoods of forming a multigenerational household through moving in with one’s adult children or grandchildren; changes in these sources did not tend to affect their propensity of having their adult children or grandchildren move in with them. 
Differences in Seniors' Assets, Debt, Retirement Income, and Social Welfare Program

Participation by Multigenerational Household Status

Seniors living in multigenerational households were more economically disadvantaged than seniors not living in multigenerational households. Seniors in multigenerational households tended to have fewer assets and less monthly retirement income. They also were less likely to receive Medicare and more likely to be enrolled in other social welfare programs, including Medicaid. Tables 9-11 report these outcomes. As before, monetary values are reported in raw and logged form. Only the main effects are reported; the demographic, socioeconomic, and temporal control variables are included in the models but suppressed on the tables. The likelihood of a senior having a zero or negative value of a monetary source is also reported.

Seniors living in multigenerational households typically had fewer assets and higher debt compared to seniors not living in multigenerational households, controlling for their demographic and socioeconomic characteristics. Living in a multigenerational household was associated with a senior having a: ${ }^{5}$

- 36 percent reduction in their IRA account value;

- 12 percent reduction in their checking account value;

- 54 percent reduction in their interest-bearing accounts value;

- 33 percent reduction in their stocks value; and

- 28 percent increase in their credit card debt.

Seniors living in multigenerational households were also more likely to report not having any assets and less likely to report not having debt than seniors not living in multigenerational households. The odds that a senior living in a multigenerational household did not have any assets ranged from 1.524 for an IRA account or stocks to 1.142 for a checking account. Living in a multigenerational household was associated with lower odds of having zero credit card debt (0.855). Living in a multigenerational household, however, made a senior more likely to have a life insurance policy.

\footnotetext{
${ }^{5}$ Effects were determined by calculating the exponentiated coefficient of the expected difference in the mean of the logged value of the source between the groups and subtracting 1 from this value. For example, the expected difference in the mean of logged IRA value between seniors living in and not living in multigenerational households is -0.441 (see Table 9). The exponentiated coefficient is $\exp (-0.441)=0.643$. Subtracting 1 from this value leads to an estimated effect of living in a multigenerational household on IRA value of -0.357 or -36 percent, holding all other factors controlled constant.
} 
Interestingly, living in a multigenerational household was not associated with differences in net worth among seniors. In fact, seniors in multigenerational households were less likely to have zero or negative net worth (odds ratio of 0.841 ). This is probably explained by the higher home equity of seniors living in multigenerational households. Living in a multigenerational household was associated with an increase in home equity of about $\$ 25,000$. Further, living in a multigenerational household was associated with much reduced odds of having zero or negative home equity (odds ratio of 0.537 ). This effect may be partly explained by the larger households and larger homes and potentially higher home values of seniors living in multigenerational households.

Seniors living in multigenerational households also received less monthly retirement income compared to seniors not living in multigenerational households. Living in a multigenerational household was associated with a senior having a:

- 23 percent reduction in all monthly retirement income, including Social Security;

- 34 percent reduction in all monthly retirement income, excluding Social Security;

- 22 percent reduction in monthly Social Security income;

- 14 percent reduction in monthly pension income; and

- 34 percent reduction in monthly interest income.

Seniors living in multigenerational households were also more likely to report not receiving any monthly retirement income (odds ratio of 2.111) or income from the disaggregated sources (odds ratios ranging from 1.625 for Social Security to 1.110 for pensions).

Finally, seniors living in multigenerational households were more likely to be enrolled in Medicaid (odds ratio of 1.197). They were less likely to be enrolled in Medicare (odds ratio of 0.524). They were not any more likely to be enrolled in social welfare programs aside from Medicare.

What explains the economic disadvantages experienced by seniors living in multigenerational households? Two potentially contributing factors were apparent in our analysis.

First, seniors living in multigenerational households had more people living in their households (average of 3.3 persons vs. 1.6 persons). More household members means more people to economically support. The responsibility to support household members may drain seniors' retirement assets and increase their debt and lead to fewer contributions to their 
retirement accounts. Drains on some assets, like interest-bearing accounts, may lead to lower monthly disbursements.

After controlling for differences in household size between seniors living and not living in multigenerational households (see effects in right hand columns of each comparison in Tables 9-11), some of the differences in assets and incomes reported above are reduced and in some cases disappear. For instance, the effect of living in a multigenerational household on the value of a checking account or total retirement income or pension income received disappears, and the effect of living in a multigenerational household on Social Security income becomes positive or disappears when it is logged.

However, some of the differences in assets, debt, retirement income, and social welfare program participation persist or become greater after controlling for household size. For instance, a small but highly statistically significant negative effect on net worth arises from living in a multigenerational household after controlling for household size (reduction of 1 percent in net worth). The positive effects of living in a multigenerational household on home equity and life insurance value disappear. The negative effects of living in a multigenerational household on the value of IRA and interest-bearing accounts, stocks, and monthly income from interest-bearing accounts and the positive effects of living in a multigenerational household on the value of debt persist. Notably, living in a multigenerational household increases the odds of a senior being enrolled in a social welfare program other than Medicare after controlling for household size (odds ratio of 1.298). These effects suggest that something else besides the greater household size of seniors living in multigenerational households is making them more economically vulnerable.

The second factor that may contribute to seniors' greater economic disadvantages in multigenerational households is that these seniors are far more likely to be living as nonhousehold heads. Thirty-two percent of seniors in multigenerational households are nonhousehold heads compared to 7 percent of all seniors (see Table 1). Seniors living as nonhousehold heads in multigenerational households are much more economically disadvantaged than seniors who are living as household heads in multigenerational households (see Tables 9 11). For instance, living as a non-household head in a multigenerational household, compared to being a household head in a multigenerational household, was associated with a:

- 4 percent reduction in net worth, mainly as an outcome of not owning a home; 
- 51 percent reduction in total monthly retirement income; and

- Increased odds of being enrolled in a social welfare program other than Medicare (1.619), including Medicaid (1.705)

Although living as a non-household head in a multigenerational households was associated with substantially less credit card debt (34 percent reduction), it was also associated with an increased likelihood of having no credit card debt (odds ratio of 1.544), possibly reflecting a lack of access to credit among these seniors. When comparing just seniors who are not household heads (see Tables 9 - 11), the effect of living in a multigenerational household on assets, debt, retirement income, and social welfare program participation disappears, with few exceptions.

Interestingly, economic disparities persist among seniors living and not living in multigenerational households among household heads. Seniors who have had their adult children or grandchildren move in with them tend to be more economically disadvantaged than seniors who are household heads and do not live with their adult children or grandchildren. For instance, after controlling for differences in their household size, living in a multigenerational household among seniors who are household heads was associated with a:

- 1 percent reduction in total net worth and an increased odds of having zero or negative net worth (1.516);

- 31 percent increase in credit card debt and a reduced odds of having zero credit card debt (0.854);

- 13 percent reduction in total retirement income, excluding Social Security, and an increased odds of having no additional retirement income aside from Social Security (1.257); and

- Increased likelihood of being enrolled in a social welfare program other than Medicare (1.469), including Medicaid (1.590).

Effect of Living in a Multigenerational Household on Seniors' Assets, Debt, Retirement Income, and Social Welfare Program Participation

A question is whether seniors' greater economic disadvantage in multigenerational households derives from characteristics and circumstances that seniors bring into multigenerational households, or whether living in a multigenerational household leads to these outcomes. Testing these hypotheses lies mainly outside of the scope of this research. However, 
we are able to observe what happens to the assets, debt, retirement income, and program participation of seniors living in multigenerational households over time while controlling for seniors' demographic and socioeconomic characteristics, which provides a glimpse into whether living in a multigenerational household may affect seniors' economic outcomes. Still, this is a tricky task due to the small number of seniors that report having many of the financial and program participation sources that we observe (e.g. under 50 percent). Having a large enough sample to examine changes in these sources among seniors living and not living in multigenerational households requires grouping seniors who have and do not have the sources together in the models. This situation makes it difficult to interpret effects, as described further below.

Tables 12 - 14 show how living in a multigenerational household changes the odds of losing assets and debt over the year and losing retirement income and becoming enrolled in a social welfare program over the past four months. The sample size for this analysis is smaller than before, because only seniors with a consistent household type over the year or past four months were included in the analysis. For instance, seniors included in the analysis of effects of living in a multigenerational household on net worth either consistently lived or did not live in a multigenerational household over the year. As before, we report only the main effects. Variables accounting for seniors' demographic and socioeconomic characteristics and temporal effects are included in the models but suppressed in the table results.

We find two trends in this analysis. First, we do not find much evidence that living in a multigenerational household increases seniors' risk of losing their assets or retirement income or becoming more in debt. Living in a multigenerational household was associated with decreased odds of losing assets or monthly retirement income with few exceptions. Living in a multigenerational household was associated with an increased odds of losing net worth or life insurance assets, credit card debt, and Social Security income, but these effects were either not statistically significant or became not statistically significant (or reversed) after controlling for multigenerational households' greater household size.

At face value, these results suggest that living in a multigenerational household has a protective effect on seniors' assets, debt, and retirement income. Yet, this is an unwarranted conclusion, as living in a multigenerational household is associated with seniors being more likely to not have many of the assets, debt, and retirement income sources examined; thus, it is 
more likely that they experience no change in the source over time ( 0 value at the start of the year or past four months and 0 value at the end of the year or past four months). Sample size issues affect our ability to just examine seniors who have each source, as earlier described.

However, a pattern that would indicate a protective or threatening effect of living in a multigenerational household on seniors' economic outcomes would be finding that they were more likely to report having a source but also less or more likely to lose the value of the source over time. We find this pattern occurring with life insurance and credit card debt, but as noted above, these effects either are not statistically significant or become statistically insignificant or reverse after controlling for household size. The only exception is when we just compare what happens to the life insurance policies of seniors who are non-household heads. Living in a multigenerational household as a non-household head is associated with a lower likelihood of having no life insurance policy, after controlling for differences in household size (odds ratio of 0.748) and a higher likelihood of losing the value of the policy over the year (odds ratio of 1.728).

This picture changes when we examine what happens to seniors' participation in social welfare programs over time. Living in a multigenerational household increased seniors' odds of being enrolled in social welfare programs aside from Medicare after controlling for differences in household size, as previously described. Living in a multigenerational household also increased the odds that a senior would enroll in a social welfare program other than Medicare over the four month study period, an effect that persists after controlling for differences in household size (odds ratio of 1.216) and household head status (odds ratio of 1.196 just comparing household heads). This is evidence in favor of the hypothesis that the multigenerational household may have a destabilizing effect on seniors' economic conditions, requiring them to seek additional government support.

\section{Effects of the Recession}

We did not find consistent evidence that the relationships between seniors' multigenerational household formation and economic outcomes described above changed during the recession. We interacted the main variables of interest (e.g. assets, debt, retirement income, social welfare program participation, or living in a multigenerational household) with the panel years to assess potential temporal effects. There were virtually no statistically significant 
temporal effects on how changes in these sources affected seniors' likelihood of forming a multigenerational household over the year or past four months, or on how living in a multigenerational household changed seniors’ propensity of losing an asset, debt or retirement income or enrolling in a social welfare program over the past year or four months. There were many statistically significant temporal effects on how living in a multigenerational household affected the value of seniors' assets, debt, and retirement income and chance of being enrolled in a social welfare program in time. However, there was seldom a consistent temporal effect across all of the years.

A few isolated effects are worth noting. First, seniors who lived in multigenerational households had much lower IRA account values than seniors who did not live in multigenerational households in the 2008 panel than in other years. This effect persisted after controlling for differences in household size and household head status. Living in a multigenerational household as a household head was associated with an 80 percent reduction in IRA account value in the 2008 panel, compared to a 28 percent to 39 percent reduction in the other panel years, relative to seniors who were households heads but not living in multigenerational households, holding other factors constant.

Second, the negative effect of being a non-household head in a multigenerational household on total monthly retirement income (including Social Security) narrowed during the recession. From 1996 to 2004, the deficit in total monthly retirement income associated with being a non-household head senior among those living in multigenerational households was close to $\$ 250$ or more. By 2008, this deficit was only about $\$ 126$. Yet, this temporal effect disappeared after logging total monthly retirement income. On whole, we did not find strong evidence that the recession changed the relationship between seniors’ multigenerational household formation and economic outcomes.

\section{Discussion and Conclusion}

We synthesize the primary contributions of our research in this section. We also consider the policy implications of our findings. 


\section{Key Takeaways}

The primary contributions of this research are fourfold. First, this research provides insight into a timely demographic trend: the increase in the formation of multigenerational households among seniors, possibly triggered by the Great Recession and possibly the growth in inequality among disadvantaged households. Seniors living in multigenerational households had distinct characteristics, which persisted over the study period. Seniors who lived in multigenerational households were more likely to live in urban areas, be Latino, Asian, or African American, be female and widowed, lack a high school degree, earn less monthly income, and be less likely to report being in good health, consistent with the literature. Seniors who moved in with their adult children and grandchildren were more likely to exhibit these characteristics. Many of the differences between seniors who were living in multigenerational households and not were still present when only examining seniors who were household heads or not household heads. Notably, seniors who moved in with their adult children or grandchildren were more likely to be Latino or Asian; those who had their adult children or grandchildren move in with them were more likely to be Latino or African American, an insight also offered in the existing literature.

Second, this research advances debates in demography, gerontology, and public policy about the role that macroeconomic changes affecting wealth (like recessions) play in household formation. Seniors living in multigenerational households, particularly those who moved in with their adult children or grandchildren, were less likely to have financial resources and more likely to receive social welfare. The economic disadvantage of seniors living in multigenerational households is partially accounted for by their larger household size and higher propensity to be non-household heads. However, seniors who had their adult children or grandchildren move in with them were more economically disadvantaged than senior household heads not living with their adult children and grandchildren, even after controlling for the former's larger households, which suggests that other factors are at play.

One potential factor is that seniors who form multigenerational households may be initially more economically disadvantaged. Indeed, we found that experiencing economic distress increased the odds of a senior forming a multigenerational household, including as a household head. Yet, other factors inherent to the dynamics of the multigenerational household 
may also affect these seniors' economic disadvantage. We were unable to capture and study these factors in our research; this is an important direction for further research.

Third, this study illuminates how multigenerational household formation affects the resilience of seniors' retirement funds and social welfare programs targeted to seniors, like Social Security, Medicare, and Medicaid. We do not find much evidence that living in a multigenerational household increases seniors' risk of losing their retirement funds. Living in a multigenerational household was associated with decreased odds of losing assets or monthly retirement income with few exceptions. Yet, seniors living in multigenerational households were also less likely to hold most of the assets and retirement income analyzed. We were unable to definitely test whether the multigenerational household had a protective effect on seniors’ economic well-being due to sample size issues. However, living in a multigenerational household increased seniors' odds of being enrolled in social welfare programs aside from Medicare. This finding persisted across different types of multigenerational households and after controlling for differences in household size. This is evidence in favor of the hypothesis that the multigenerational household may have a destabilizing effect on seniors' economic conditions, requiring them to seek additional government support.

Fourth, we did not find consistent evidence of temporal effects. There were virtually no statistically significant temporal effects on how changes in seniors' assets, debt, retirement income, or social welfare program participation affected their likelihood of forming a multigenerational household over the year or past four months, or on how living in a multigenerational household changed their propensity of losing an asset, debt or retirement income or enrolling in a social welfare program over the year or past four months. On whole, we do not find strong evidence that the recession changed the relationship between seniors' multigenerational household formation and economic outcomes.

\section{Policy Implications}

Public policymakers may use our findings to make better decisions about how to encourage and support multigenerational households and connect this type of household to programs established by the U.S. Department of Housing and Urban Development (HUD), the Department of Health and Human Services (DHHS), or the Social Security Administration (SSA). Seniors living in multigenerational households are a group increasingly worthy of policy 
attention. However, it is critical to differentiate between seniors who are household heads and not household heads in multigenerational households, as their characteristics and outcomes are different. This study finds that seniors who live in multigenerational households of different types are more likely to become enrolled in a social welfare program. This trend may be helping to destabilize these programs. Policymakers may want to target financial education and counseling to seniors living in multigenerational households. However, more research is needed to understand what makes these seniors more economically vulnerable.

Further, there may be important benefits of multigenerational living for seniors that are not captured by this research. For instance, forming a multigenerational household may counter or prevent loneliness, which is prevalent among many seniors. ${ }^{6}$ Policymakers could benefit by weighing the potential economic and non-economic benefits and costs of multigenerational living for seniors in devising solutions.

\footnotetext{
${ }^{6}$ For example, a nationwide survey administered by the AARP showed that 35 percent of survey respondents reported being lonely. Age, income, and marital status were significantly related to loneliness, with 51 percent of never-married respondents reporting experiencing loneliness (Knowledge Networks and Insight Policy Research, 2010). Given the increasing proportion of never-married people and of single households, loneliness will most likely become an even larger policy concern (Klinenberg, 2012).
} 


\section{References}

Allen, T. M., Petroni, R. J., and R. P. Singh. 1993. The Effectiveness of Oversampling Low Income Households in the Survey of Income and Program Participation. Washington, DC: U.S. Bureau of the Census.

Angel, R., and M. Tienta. 1982. "Determinants of Extended Household Structure: Cultural Pattern or Economic Need?” American Journal of Sociology 87(6): 1360-1383.

Aquilino, W. S. 1990. "The Likelihood of Parent-Adult Child Coresidence: Effects of Family Structure and Parental Characteristics.” Journal of Marriage and the Family 52(May): 405-419.

Bentson, V. L. (2001). “The Burgess Award Lecture: Beyond the Nuclear Family: The Increasing Importance of Multigenerational Bonds.” Journal of Marriage and Family 63(1): 1-16.

Bethell, T. 2011. Family Matters: Multigenerational Families in a Volatile Economy. Washington, DC: Generations United.

Billings, D. B. and K. M. Blee. 1990. "Family Strategies in a Subsistence Economy: Beech Creek, Kentucky, 1850-1942.” Sociological Perspectives 33(1): 63-88.

Bureau of Labor Statistics. 2014. Labor Force Statistics from the Current Population Survey. Washington, D.C.: Bureau of Labor Statistics.

Burr, J. A., and J. E. Mutchler. 1992. “The Living Arrangements of Unmarried Elderly Hispanic Females.” Demography 29(1): 93-112.

Burr, J. A., J. E. Mutchler, and K. Gerst-Emerson. 2013. "Residential Segregation, Nativity Status, and Hispanic Living Arrangements in Later Life.”

Butrica, B. A. 2013. Retirement Plan Assets. Washington, DC: Urban Institute.

Choi, N. G. 1997. "Changes in the Composition of Unmarried Elderly Women’s Households between 1971 and 1991.” Journal of Gerontological Social Work 27(1/2): 113-131.

Choi, N. G. 1999a. "Living Arrangements and Household Compositions of Elderly Couples and Singles.” Journal of Gerontological Social Work 31(1/2): 41-61.

Choi, N. G. 1999b. "No Longer Independent: The Dynamics of Care Arrangements for Frail Elderly Parents.” Journal of Gerontological Social Work 32(3): 27-47.

Choi, N. G. 2003. “Nonmarried Aging Parents’ and Their Adult Children’s Characteristics Associated with Transitions Into and Out of Intergenerational Coresidence.” Journal of Gerontological Social Work 40(3): 7-29. 
Chu, C. Y. C., Y. Xie, and R. R. Yu. 2011. "Coresidence with Elderly Parents: A Comparative Study of Southeast China and Taiwan.” Journal of Marriage and Family 73(February): 120-135.

Cohen, P. N., and L. M. Casper. 2002. "In Whose Home? Multigenerational Families in the United States, 1998-2000.” Sociological Perspectives 45(1): 1-20.

Dunifon, R. E., K. M. Ziol-Guest, and K. Kopko. 2014. “Grandparent Coresidence and Family Well-Being: Implications for Research and Policy.” The ANNALS of the American Academy of Political and Social Science 654 (July): 110-126.

Elliott, D. B, R. Young, and J. L. Dye. 2011. Variation in the Formation of Complex Family Households during the Recession. SEHSD Working Paper Number 2011-32. Washington, DC: U.S. Bureau of the Census.

Elman, C. and P. Uhlenberg. 1995. "Co-residence in the Early Twentieth Century: Elderly Women in the United STates and Their Children.” Population Studies 49: 501-517.

Firman, J., S. Nathan, and R. Alwin. 2009. "Meeting the Needs of Economically Disadvantaged Older Adults: A Holistic Approach to Economic Casework.” Generations 33(3): 74-80.

Frankenberg, E. A. Chan, and M. B. Ofstedal. 2002. "Stability and Change in Living Arrangements in Indonesia, Singapore, and Taiwan, 1993-99.” Population Studies 56: 201-213.

Glick, J. E. and J. Van Hook. 2011. "Does a House Divided Stand? Kinship and the Continuity of Shared Living Arrangements.” Journal of Marriage and Family 73(5): 1149-1164.

Goldscheider, F. K. and R. M. Bures. 2003. "The Racial Crossover in Family Complexity in the United States.” Demography 40(3): 569-587.

Goldscheider, F. K., and L. Lawton. 1998. "Family Experiences and the Erosion of Support for Intergenerational Coresidence.” Journal of Marriage and the Family 60: 623-632.

Gonzales, A. M. 2007. "Determinants of Parent-Child Coresidence among Older Mexican Parents: The Salience of Cultural Values.” Sociological Perspectives 50(4): 561-577.

Grundy, E. 2000. “Co-residence of Mid-life Children with their Elderly Parents in England and Wales: Changes between 1981 and 1991.” Population Studies 54: 193-206.

Gurak, D. T., and M. M. Kritz. 2010. "Elderly Asian and Hispanic Foreign- and Native-Born Living Arrangements: Accounting for Differences.” Research on Aging 32(5): 567-594.

Harrell, R., E. Kassner, and C. Figueiredo. 2011. "Multigenerational Households Are Increasing.” AARP Public Policy Institute Fact Sheet, 221, 1-3. 
Hayutin, A. M. 2012. “Changing Demographic Realities.” In H. Cisneros, M. Dyer-Chamberlain, \& J. Hickie (Eds.), Independent for life: Homes and neighborhoods for an aging America (pp. 35-44). Austin, TX: University of Texas Press.

Isengard, B. and M. Szydlik. 2012. "Living Apart (or) Together? Coresidence of Elderly Parents and their Adult Children in Europe.” Research on Aging 34(4): 449-474.

Jackson, K. T. 1985. Crabgrass Frontier: The Suburbanization of the United States. New York, NY: Oxford University Press.

Joint Center for Housing Studies of Harvard University. 2012. The State of the Nation's Housing. Cambridge, MA: Joint Center for Housing Studies of Harvard University.

Joint Center for Housing Studies of Harvard University. 2013. America's Rental Housing: Evolving Markets and Needs. Cambridge, MA: Joint Center for Housing Studies of Harvard University.

Kamo, Y. 2000. "Racial and Ethnic Differences in Extended Family Households.” Sociological Perspectives 43(2): 211-229.

Keene, J. R. and C. D. Batson. 2010. "Under One Roof: A Review of Research on Intergenerational Coresidence and Multigenerational Households in the United States.” Sociological Compass 4(8): 642-657.

Kim, J. and L. J. Waite. 2016. “Complex Households and the Distribution of Multiple Resources in Later Life: Findings from a National Survey. Research on Aging 38(2): 150-177.

Klinenberg, E. 2012. Going Solo: The Extraordinary Rise and Surprising Appeal of Living Alone. New York: Penguin.

Knowledge Networks and Insight Policy Research. 2010. Loneliness among Older Adults: A National Survey of Adults 45+. Washington, DC: AARP.

Kochhar, Rakesh, Richard Fry, and Molly Rohal. 2015. The American Middle Class Is Losing Ground. Washington, D.C.: Pew Research Center.

Kok, J. and K. Mandemakers. 2010. “A Life-course Approach to Co-residence in the Netherlands, 1850-1940.” Continuity and Change 25: 285-312.

Liebig, P. S., T. Koenig, and J. Pynoos. 2006. “Zoning, Accessory Dwelling Units, and Family Caregiving.” Journal of Aging \& Social Policy 18: 155-172.

Lusardi, A. and O. S. Mitchell. 2013. “Older Adult Debt and Financial Frailty.” Working Paper WP 2013-291. Ann Arbor, MI: Michigan Retirement Research Center, University of Michigan. 
Macunovich, D. J., R. A. Easterlin, C. M. Schaeffer, and E. M. Crimmins. 1995. "Echoes of the Baby Boom and Bust: Recent and Prospective Changes in Living Alone among Elderly Widows in the United States.” Demography 32(1): 17-28.

Martin, L. G. 1989. "Living Arrangements of the Elderly in Fiji, Korea, Malaysia, and the Philippines.” Demography 26(4): 627-643.

Messineo, M. 2005. "Influence of Expectations for Parental Support on Intergenerational Coresidence Behavior.” Journal of Intergenerational Relationships 3(3): 47-64.

Morgan, S. P., A. McDaniel, A. T. Miller, and S. H. Preston. 1993. "Racial Differences in Household and Family Structure at the Turn of the Century.” American Journal of Sociology 98(4): 798-828.

Mutchler, J. E. 1992. "Living Arrangements and Household Transitions among the Unmarried in Later Life.” Social Science Quarterly 73(3): 565-580.

Mutchler, J. E. and L. A. Baker. 2009. “The Implications of Grandparent Coresidence for Economic Hardship among Children in Mother-only Families.” Journal of Family Issues 30(11): 1576-1597.

Mutchler, J. E. and J. A. Burr. 1991. “A Longitudinal Analysis of Household and Nonhousehold Living Arrangements in Later Life.” Demography 28(3): 375-390.

Mutchler, J. E. and J. A. Burr. 2003. “Living Arrangements among Older Persons.” Research on Aging 25(6): 531-558.

Mykyta, L. and S. Macartney. 2011. The Effects of Recession on Household Composition: "Doubling Up" and Economic Well-being. SEHSD Working Paper Number 2011-4. Washington, DC: U.S. Bureau of the Census.

Oberlander, S. E., F. M. Shebl, L. S. Magder, and M. M. Black. 2009. “Adolescent Mothers Leaving Multigenerational Households.” Journal of Clinical Child and Adolescent Psychology 38(1): 62-74.

Pfeiffer, D. 2015. "Retrofitting Suburbia through Second Units: Lessons from the Phoenix Region.” Journal of Urbanism 8(3): 279-301.

Pilkauskas, N. V. 2012. “Three-generation Family Households: Differences by Family Structure at Birth.” Journal of Marriage and Family 74(October): 931-943.

Ruggles, S. 2003. “Multigenerational families in Nineteenth-century America.” Continuity and Change 18(1): 139-165.

Ruggles, S. 2007. “The Decline of Intergenerational Coresidence in the United States, 1850 to 2000.” American Sociological Review 72(6): 964-989. 
Smits, A., R. I. van Gaalen, and C. H. Mulder. 2010. "Parent-Child Coresidence: Who Moves in With Whom and for Whose Needs?” Journal of Marriage and Family 72(August): 10221033.

Takagi, E., and M. Silverstein. 2011. "Purchasing Piety? Coresidence of Married Children with their Older Parents in Japan.” Demography 48(4): 1559-1579.

Taylor, P., R. Kochhar, D. Cohn, J. S. Passel, G. Velasco, S. Motel, and E. Patton. 2011. Fighting Poverty in a Tough Economy, Americans Move in with Their Relatives. Washington, DC: Pew Research Center.

Taylor, P., R. Morin, W. Wang, J. S. Passel, and D. Dockterman. 2009. Recession Brings Many Young People Back to the Nest: Home for the Holidays... and Every Other Day. Washington, DC: Pew Research Center.

Thayer, C. 2007. Preparation for Retirement: The Haves and Have-Nots. Washington, DC: AARP Knowledge Management.

U.S. Census Bureau. 2009. Survey of Income and Program Participation Users’ Guide. Revised chapters included as supplement to the Third Edition published in 2001. Washington, D.C.: U.S. Bureau of the Census. Available at: http://www.census.gov/sipp/.

U.S. Census Bureau. Various Years. Survey of Income and Program Participation (SIPP) 1996, 2001, 2004, and 2008 Panel Core and Topical Wave Files. Washington, D.C.: U.S. Bureau of the Census. Available at: http://www.census.gov/sipp/.

Valk, H. A. G. de, and F. C. Billari. 2007. “Living Arrangements of Migrant and Dutch Young Adults: Fhe Family Influence Disentangled.” Population Studies 61(2): 201-217.

Van Hook, J., and J. E. Glick. 2007. "Immigration and Living Arrangements: Moving beyond Economic Need versus Acculturation.” Demography 44(2): 225-249.

Waehrer, K., and S. Crystal. 1995. "The Impact of Coresidence on Economic Well-being of Elderly Widows.” Journal of Gerontology 50(4): S250-S258.

Wilmoth, J. M. 2001. “Living Arrangements among Older Immigrants in the United States.” The Gerontologist 41(2): 228-238.

Wolf, D. A., and B. J. Soldo. 1988. "Household Composition Choices of Older Unmarried Women.” Demography 25(3): 387-403.

Zillow.com. n.d. United States Home Prices and Values. Seattle, WA: Zillow.com.

Zimmer, Z. and J. Dayton. 2005. "Older Adults in Sub-Saharan Africa Living with Children and Grandchildren.” Population Studies 59(3): 295-312. 
Zsembik, B. A. 1992. "Determinants of Living Alone Among Older Hispanics.” Research on Aging 15(4): 449-464. 
Table 1: Sample Characteristics, 1996 - 2008 Panels

\begin{tabular}{lc}
\hline Seniors & 49,346 \\
$\%$ Ever Living in Multigenerational Household & $20 \%-22 \%$ \\
$\%$ Always Living in Multigenerational Household & $11 \%-14 \%$ \\
Seniors by Wave & 341,528 \\
$\%$ in Multigenerational Household & $17 \%$ \\
$\%$ Household Head & $68 \%$ \\
$\%$ Non-Household Head & $32 \%$ \\
$\%$ Household Head & $93 \%$ \\
$\%$ of Household Heads Living in Multigenerational Households & $12 \%$ \\
$\%$ Non-Household Head & $7 \%$ \\
$\%$ of Non-Household Heads Living in Multigenerational Households & $76 \%$ \\
$\%$ Moved to Multigenerational Household over Year & $1 \%$ \\
$\%$ Became Household Head & $1 \%$ \\
$\%$ Became Non-Household Head & $<1 \%$ \\
$\%$ Moved to Non-Multigenerational Household over Year & $1 \%$ \\
$\%$ Became Household Head & $<1 \%$ \\
$\%$ Became Non-Household Head & $<1 \%$ \\
\hline
\end{tabular}

Source: Survey of Income and Program Participation, 1996 - 2008 panels 
Table 2: Assets, Debt, Retirement Income, and Social Welfare Programs Analyzed

\begin{tabular}{lc}
\hline \multicolumn{1}{c}{ Source } & $\begin{array}{c}\text { \% of Seniors } \\
\text { Reporting } \\
\text { Source }\end{array}$ \\
\hline \hline Net Worth & 97 \\
Home Equity & 83 \\
Interest Account & 65 \\
Life Insurance & 50 \\
Checking Account & 25 \\
IRA & 22 \\
Stocks & 20 \\
Credit Card Debt & 24 \\
Retirement Income & 96 \\
Social Security & 92 \\
Retirement Income Excluding Social Security & 70 \\
Interest Payments & 48 \\
Pension & 38 \\
Social Welfare Program & 96 \\
Medicare & 94 \\
Social Welfare Program Excluding Medicare & 16 \\
Medicaid & 10 \\
\hline
\end{tabular}

Source: Survey of Income and Program Participation, 1996 - 2008 panels

Note: Sources owned jointly and solely are combined; composite variables like net worth, retirement income, and social welfare program participation contain many more sources than are disaggregated on the table; only sources reported by at least $10 \%$ of seniors were analyzed separately. 
Table 3: Seniors' Characteristics by Multigenerational Household Formation (Part 1 of 2)

\begin{tabular}{|c|c|c|c|c|c|c|c|c|}
\hline \multirow[b]{2}{*}{ Characteristics } & \multicolumn{2}{|c|}{ Seniors } & \multicolumn{2}{|c|}{ Multigen Household Seniors } & \multicolumn{2}{|c|}{ Household Head Seniors } & \multicolumn{2}{|c|}{$\begin{array}{c}\text { Non-Household Head } \\
\text { Seniors }\end{array}$} \\
\hline & $\begin{array}{l}\text { Multigen } \\
\text { Household }\end{array}$ & $\begin{array}{c}\text { Non- } \\
\text { Multigen } \\
\text { Household }\end{array}$ & $\begin{array}{l}\text { Household } \\
\text { Head }\end{array}$ & $\begin{array}{c}\text { Non- } \\
\text { Household } \\
\text { Head }\end{array}$ & $\begin{array}{l}\text { Multigen } \\
\text { Household }\end{array}$ & $\begin{array}{c}\text { Non- } \\
\text { Multigen } \\
\text { Household }\end{array}$ & $\begin{array}{l}\text { Multigen } \\
\text { Household }\end{array}$ & $\begin{array}{c}\text { Non- } \\
\text { Multigen } \\
\text { Household }\end{array}$ \\
\hline \multicolumn{9}{|c|}{ Core Wave Variables, Point in Time } \\
\hline Lives in urban area & $83 \%$ & $77 \%$ & $81 \%$ & $86 \%$ & $81 \%$ & $76 \%$ & $86 \%$ & $83 \%$ \\
\hline Non-Hispanic white & $67 \%$ & $87 \%$ & $70 \%$ & $60 \%$ & $70 \%$ & $87 \%$ & $60 \%$ & $78 \%$ \\
\hline Latino & $13 \%$ & $4 \%$ & $11 \%$ & $18 \%$ & $11 \%$ & $4 \%$ & $18 \%$ & $8 \%$ \\
\hline African American & $14 \%$ & $7 \%$ & $16 \%$ & $10 \%$ & $16 \%$ & $7 \%$ & $10 \%$ & $11 \%$ \\
\hline Asian & $6 \%$ & $2 \%$ & $4 \%$ & $12 \%$ & $4 \%$ & $2 \%$ & $12 \%$ & $3 \%$ \\
\hline Age $85+$ & $9 \%$ & $7 \%$ & $6 \%$ & $15 \%$ & $6 \%$ & $7 \%$ & $15 \%$ & $7 \%$ \\
\hline Female & $64 \%$ & $57 \%$ & $60 \%$ & $71 \%$ & $60 \%$ & $57 \%$ & $71 \%$ & $53 \%$ \\
\hline Married & $41 \%$ & $57 \%$ & $52 \%$ & $20 \%$ & $52 \%$ & $58 \%$ & $20 \%$ & $5 \%$ \\
\hline Widowed & $47 \%$ & $30 \%$ & $38 \%$ & $63 \%$ & $38 \%$ & $30 \%$ & $63 \%$ & $34 \%$ \\
\hline Divorced or separated & $10 \%$ & $9 \%$ & $8 \%$ & $12 \%$ & $8 \%$ & $8 \%$ & $12 \%$ & $33 \%$ \\
\hline Single & $3 \%$ & $4 \%$ & $2 \%$ & $5 \%$ & $2 \%$ & $4 \%$ & $5 \%$ & $28 \%$ \\
\hline No high school degree & $38 \%$ & $24 \%$ & $34 \%$ & $45 \%$ & $34 \%$ & $24 \%$ & $45 \%$ & $35 \%$ \\
\hline High school degree & $33 \%$ & $32 \%$ & $33 \%$ & $33 \%$ & $33 \%$ & $32 \%$ & $33 \%$ & $31 \%$ \\
\hline Some college & $19 \%$ & $25 \%$ & $22 \%$ & $13 \%$ & $22 \%$ & $25 \%$ & $13 \%$ & $18 \%$ \\
\hline College degree & $7 \%$ & $11 \%$ & $7 \%$ & $5 \%$ & $7 \%$ & $11 \%$ & $5 \%$ & $10 \%$ \\
\hline Professional degree & $4 \%$ & $8 \%$ & $5 \%$ & $3 \%$ & $5 \%$ & $8 \%$ & $3 \%$ & $6 \%$ \\
\hline At least some college & $30 \%$ & $44 \%$ & $34 \%$ & $22 \%$ & $34 \%$ & $44 \%$ & $22 \%$ & $34 \%$ \\
\hline Lives in owned home & $85 \%$ & $82 \%$ & $87 \%$ & $81 \%$ & $87 \%$ & $82 \%$ & $81 \%$ & $76 \%$ \\
\hline Personal monthly income & $\$ 1,819$ & $\$ 2,322$ & $\$ 2,051$ & $\$ 1,382$ & $\$ 2,051$ & $\$ 2,333$ & $\$ 1,382$ & $\$ 1,863$ \\
\hline Total persons in household & 3.3 & 1.6 & 3.1 & 3.8 & 3.1 & 1.6 & 3.8 & 2.4 \\
\hline Observations & \multicolumn{2}{|c|}{341,528} & \multicolumn{2}{|c|}{56,391} & \multicolumn{2}{|c|}{317,802} & \multicolumn{2}{|c|}{23,726} \\
\hline
\end{tabular}

Source: Survey of Income and Program Participation, 1996 - 2008 panels

$p<.01 ; p<.05 ; p<.10$

Note: Population estimates reported. 


\begin{tabular}{|c|c|c|c|c|c|c|c|c|}
\hline \multirow[b]{2}{*}{ Characteristics } & \multicolumn{2}{|c|}{ Seniors } & \multicolumn{2}{|c|}{ Multigen Household Seniors } & \multicolumn{2}{|c|}{ Household Head Seniors } & \multicolumn{2}{|c|}{$\begin{array}{l}\text { Non-Household Head } \\
\text { Seniors }\end{array}$} \\
\hline & $\begin{array}{l}\text { Multigen } \\
\text { Household }\end{array}$ & $\begin{array}{c}\text { Non- } \\
\text { Multigen } \\
\text { Household }\end{array}$ & $\begin{array}{l}\text { Household } \\
\text { Head }\end{array}$ & $\begin{array}{c}\text { Non- } \\
\text { Household } \\
\text { Head }\end{array}$ & $\begin{array}{l}\text { Multigen } \\
\text { Household }\end{array}$ & $\begin{array}{c}\text { Non- } \\
\text { Multigen } \\
\text { Household }\end{array}$ & $\begin{array}{l}\text { Multigen } \\
\text { Household }\end{array}$ & $\begin{array}{c}\text { Non- } \\
\text { Multigen } \\
\text { Household }\end{array}$ \\
\hline \multicolumn{9}{|l|}{$\begin{array}{l}\text { Core Wave Variables, Change over Past } \\
\text { Four Months }\end{array}$} \\
\hline Became unmarried & $1 \%$ & $1 \%$ & $1 \%$ & $1 \%$ & $1 \%$ & $1 \%$ & $1 \%$ & $1 \%$ \\
\hline Became married & $0 \%$ & $0 \%$ & $0 \%$ & $0 \%$ & $0 \%$ & $0 \%$ & $0 \%$ & $0 \%$ \\
\hline Became widowed & $1 \%$ & $1 \%$ & $1 \%$ & $1 \%$ & $1 \%$ & $1 \%$ & $1 \%$ & $1 \%$ \\
\hline Change in personal monthly income & $129 \%$ & $73 \%$ & $142 \%$ & $105 \%$ & $142 \%$ & $73 \%$ & $105 \%$ & $65 \%$ \\
\hline Change in total persons in household & 0.02 & -0.01 & 0.02 & 0.01 & 0.02 & -0.01 & 0.01 & 0.00 \\
\hline Observations & \multicolumn{2}{|c|}{287,346} & \multicolumn{2}{|c|}{47,082} & \multicolumn{2}{|c|}{267,892} & \multicolumn{2}{|c|}{19,454} \\
\hline \multicolumn{9}{|l|}{ Topical Wave Variables, Point in Time } \\
\hline Owns a home & $56 \%$ & $75 \%$ & $80 \%$ & $11 \%$ & $80 \%$ & $76 \%$ & $11 \%$ & $21 \%$ \\
\hline Reports being in good health & $59 \%$ & $69 \%$ & $63 \%$ & $51 \%$ & $63 \%$ & $69 \%$ & $51 \%$ & $61 \%$ \\
\hline Observations & \multicolumn{2}{|c|}{76,125} & \multicolumn{2}{|c|}{12,566} & \multicolumn{2}{|c|}{70,871} & \multicolumn{2}{|c|}{5,254} \\
\hline \multicolumn{9}{|l|}{ Topical Wave Variables, Change over } \\
\hline \multicolumn{9}{|l|}{ Year } \\
\hline Became homeowner & $3 \%$ & $2 \%$ & $2 \%$ & $3 \%$ & $2 \%$ & $2 \%$ & $3 \%$ & $6 \%$ \\
\hline Became not a homeowner & $4 \%$ & $2 \%$ & $3 \%$ & $6 \%$ & $3 \%$ & $2 \%$ & $6 \%$ & $5 \%$ \\
\hline Had worse health & $14 \%$ & $12 \%$ & $14 \%$ & $16 \%$ & $14 \%$ & $12 \%$ & $16 \%$ & $17 \%$ \\
\hline Had better health & $12 \%$ & $10 \%$ & $12 \%$ & $14 \%$ & $12 \%$ & $10 \%$ & $14 \%$ & $11 \%$ \\
\hline Observations & \multicolumn{2}{|c|}{34,849} & \multicolumn{2}{|c|}{5,692} & \multicolumn{2}{|c|}{32,545} & \multicolumn{2}{|c|}{2,304} \\
\hline
\end{tabular}

Source: Survey of Income and Program Participation, 1996 - 2008 panels

$p<.01 ; p<.05 ; p<.10$

Note: Population estimates reported. 


\begin{tabular}{|c|c|c|c|c|c|c|c|c|}
\hline \multirow[t]{2}{*}{ Characteristics } & \multicolumn{2}{|c|}{$\begin{array}{l}\text { Odds of Living in a Multigen } \\
\text { Household, All Seniors }\end{array}$} & \multicolumn{2}{|c|}{$\begin{array}{l}\text { Odds of Living as a Non- } \\
\text { Household Head in a } \\
\text { Multigen Household, } \\
\text { Seniors in Multigen } \\
\text { Households }\end{array}$} & \multicolumn{2}{|c|}{$\begin{array}{c}\text { Odds of Living in a Multigen } \\
\text { Household, Household } \\
\text { Head Seniors }\end{array}$} & \multicolumn{2}{|c|}{$\begin{array}{c}\text { Odds of Living in a Multigen } \\
\text { Household, Non-Household } \\
\text { Head Seniors }\end{array}$} \\
\hline & $\begin{array}{c}\text { Core } \\
\text { Waves }\end{array}$ & $\begin{array}{l}\text { Topical } \\
\text { Waves }\end{array}$ & $\begin{array}{c}\text { Core } \\
\text { Waves }\end{array}$ & $\begin{array}{l}\text { Topical } \\
\text { Waves }\end{array}$ & $\begin{array}{c}\text { Core } \\
\text { Waves }\end{array}$ & $\begin{array}{l}\text { Topical } \\
\text { Waves }\end{array}$ & $\begin{array}{c}\text { Core } \\
\text { Waves }\end{array}$ & $\begin{array}{l}\text { Topical } \\
\text { Waves }\end{array}$ \\
\hline \multicolumn{9}{|c|}{ Race (Non-Hispanic White Omitted) } \\
\hline African American & $\begin{array}{c}3.486 \\
(0.205) \\
2.137\end{array}$ & $\begin{array}{c}3.227 \\
(0.202) \\
1.995\end{array}$ & $\begin{array}{c}2.021 \\
(0.223) \\
0.681\end{array}$ & $\begin{array}{c}1.408 \\
(0.190) \\
0.558\end{array}$ & $\begin{array}{c}2.703 \\
(0.207) \\
2.404\end{array}$ & $\begin{array}{c}2.898 \\
(0.230) \\
2.475\end{array}$ & $\begin{array}{c}3.346 \\
(0.633) \\
1.252\end{array}$ & $\begin{array}{c}2.963 \\
(0.584) \\
1.088\end{array}$ \\
\hline Afrıcan American & $\begin{array}{c}(0.110) \\
5.056\end{array}$ & $\begin{array}{c}(0.108) \\
4.468\end{array}$ & $\begin{array}{c}(0.064) \\
4.528\end{array}$ & $\begin{array}{c}(0.070) \\
2.765\end{array}$ & $\begin{array}{c}(0.137) \\
2.816\end{array}$ & $\begin{array}{c}(0.145) \\
3.283\end{array}$ & $\begin{array}{c}(0.232) \\
6.684\end{array}$ & $\begin{array}{c}(0.208) \\
6.603\end{array}$ \\
\hline Asian & $\begin{array}{c}(0.371) \\
0.997\end{array}$ & $\begin{array}{c}(0.348) \\
1.013\end{array}$ & $\begin{array}{c}(0.702) \\
1.096\end{array}$ & $\begin{array}{c}(0.497) \\
1.005\end{array}$ & $\begin{array}{c}(0.300) \\
0.953\end{array}$ & $\begin{array}{c}(0.375) \\
0.976\end{array}$ & $\begin{array}{c}(2.130) \\
1.565\end{array}$ & $\begin{array}{c}(2.065) \\
1.518\end{array}$ \\
\hline Female & $\begin{array}{c}(0.027) \\
0.995\end{array}$ & $\begin{array}{c}(0.028) \\
0.991\end{array}$ & $\begin{array}{c}(0.070) \\
1.068\end{array}$ & $\begin{array}{c}(0.080) \\
1.064\end{array}$ & $\begin{array}{c}(0.027) \\
0.973\end{array}$ & $\begin{array}{c}(0.029) \\
0.971\end{array}$ & $\begin{array}{c}(0.170) \\
1.056\end{array}$ & $\begin{array}{c}(0.173) \\
1.050\end{array}$ \\
\hline Widomed & $\begin{array}{c}(0.003) \\
2.049\end{array}$ & $\begin{array}{c}(0.003) \\
1.918\end{array}$ & $\begin{array}{c}(0.006) \\
2.262\end{array}$ & $\begin{array}{c}(0.008) \\
2.047\end{array}$ & $\begin{array}{c}(0.003) \\
1.592\end{array}$ & $\begin{array}{c}(0.003) \\
1.650\end{array}$ & $\begin{array}{c}(0.008) \\
2.720\end{array}$ & $\begin{array}{c}(0.009) \\
2.711\end{array}$ \\
\hline Widowed & $(0.073)$ & $(0.073)$ & $(0.163)$ & $(0.187)$ & $(0.067)$ & $(0.074)$ & $(0.328)$ & $(0.340)$ \\
\hline \multicolumn{9}{|c|}{ Education (Some College or More Omitted) } \\
\hline No high school degree & $\begin{array}{c}1.565 \\
(0.065) \\
1.331\end{array}$ & $\begin{array}{c}1.424 \\
(0.065) \\
1.290\end{array}$ & $\begin{array}{c}1.327 \\
(0.109) \\
1.257\end{array}$ & $\begin{array}{c}0.976 \\
(0.104) \\
1.154\end{array}$ & $\begin{array}{c}1.420 \\
(0.065) \\
1.243\end{array}$ & $\begin{array}{c}1.462 \\
(0.074) \\
1.229\end{array}$ & $\begin{array}{c}1.434 \\
(0.184) \\
1.329\end{array}$ & $\begin{array}{c}1.325 \\
(0.187) \\
1.314\end{array}$ \\
\hline High school degree & $\begin{array}{c}(0.058) \\
1.000\end{array}$ & $\begin{array}{c}(0.063) \\
1.000\end{array}$ & $\begin{array}{c}(0.102) \\
1.000\end{array}$ & $\begin{array}{c}(0.137) \\
1.000\end{array}$ & $\begin{array}{c}(0.065) \\
1.000\end{array}$ & $\begin{array}{c}(0.071) \\
1.000\end{array}$ & $\begin{array}{c}(0.172) \\
1.000\end{array}$ & $\begin{array}{c}(0.186) \\
1.000\end{array}$ \\
\hline Personal monthly income & $(0.000)$ & $\begin{array}{c}(0.000) \\
0.825\end{array}$ & $(0.000)$ & $\begin{array}{c}(0.000) \\
0.847\end{array}$ & $(0.000)$ & $\begin{array}{c}(0.000) \\
0.837\end{array}$ & $(0.000)$ & $\begin{array}{c}(0.000) \\
0.812\end{array}$ \\
\hline Reports being in good health & & $\begin{array}{c}(0.023) \\
0.611\end{array}$ & & $\begin{array}{c}(0.058) \\
0.036\end{array}$ & & $\begin{array}{c}(0.026) \\
1.701\end{array}$ & & $\begin{array}{c}(0.075) \\
0.610\end{array}$ \\
\hline Owns a home & & $(0.020)$ & & $(0.003)$ & & $(0.075)$ & & $(0.076)$ \\
\hline \multicolumn{9}{|l|}{ Panel (2008 omitted) } \\
\hline 1996 & $\begin{array}{c}0.930 \\
(0.037) \\
0.905\end{array}$ & $\begin{array}{c}0.951 \\
(0.042) \\
0.927\end{array}$ & $\begin{array}{c}0.976 \\
(0.084) \\
0.923\end{array}$ & $\begin{array}{c}1.007 \\
(0.103) \\
0.981\end{array}$ & $\begin{array}{c}0.956 \\
(0.048) \\
0.921\end{array}$ & $\begin{array}{c}0.943 \\
(0.052) \\
0.908\end{array}$ & $\begin{array}{c}0.649 \\
(0.091) \\
1.001\end{array}$ & $\begin{array}{c}0.661 \\
(0.100) \\
1.083\end{array}$ \\
\hline 2001 & $\begin{array}{c}(0.043) \\
0.966\end{array}$ & $\begin{array}{c}(0.046) \\
0.977\end{array}$ & $\begin{array}{c}(0.086) \\
1.007\end{array}$ & $\begin{array}{c}(0.115) \\
1.030\end{array}$ & $\begin{array}{c}(0.048) \\
0.964\end{array}$ & $\begin{array}{c}(0.049) \\
0.950\end{array}$ & $\begin{array}{c}(0.168) \\
0.881\end{array}$ & $\begin{array}{c}(0.199) \\
0.892\end{array}$ \\
\hline 2004 & $\begin{array}{c}(0.048) \\
0.167\end{array}$ & $\begin{array}{c}(0.051) \\
0.329\end{array}$ & $\begin{array}{c}(0.086) \\
0.003\end{array}$ & $\begin{array}{c}(0.107) \\
0.018\end{array}$ & $\begin{array}{c}(0.052) \\
0.674\end{array}$ & $\begin{array}{c}(0.055) \\
0.526\end{array}$ & $\begin{array}{c}(0.152) \\
0.018\end{array}$ & $\begin{array}{c}(0.165) \\
0.034\end{array}$ \\
\hline Constant & $(0.037)$ & $(0.080)$ & $(0.001)$ & $(0.010)$ & $(0.176)$ & $(0.150)$ & $(0.011)$ & $(0.021)$ \\
\hline Observations & 341,528 & 76,125 & 56,391 & 12,566 & 317,802 & 70,871 & 23,726 & 5,254 \\
\hline Prob $>\mathrm{F}$ & 0.000 & 0.000 & 0.000 & 0.000 & 0.000 & 0.000 & 0.000 & 0.000 \\
\hline
\end{tabular}

Source: Survey of Income and Program Participation, 1996 - 2008 panels

Note: $p<.01 ; p<.05 ; p<.10$; standard errors in parentheses. Population estimates reported. Waves controlled but estimates suppressed. 
Table 5: Factors Affecting a Senior's Propensity of Forming a Multigenerational Household

\begin{tabular}{|c|c|c|c|}
\hline Characteristics & $\begin{array}{l}\text { Odds of } \\
\text { Forming a } \\
\text { Multigen } \\
\text { Household }\end{array}$ & $\begin{array}{c}\text { Odds of } \\
\text { Forming a } \\
\text { Multigen } \\
\text { Household as a } \\
\text { Household } \\
\text { Head }\end{array}$ & $\begin{array}{c}\text { Odds of } \\
\text { Forming a } \\
\text { Multigen } \\
\text { Household as a } \\
\text { Non-Household } \\
\text { Head }\end{array}$ \\
\hline \multicolumn{4}{|l|}{ Race (Non-Hispanic White Omitted) } \\
\hline Latino & $\begin{array}{c}2.663 \\
(0.579) \\
2.146\end{array}$ & $\begin{array}{c}2.699 \\
(0.602) \\
2.230\end{array}$ & $\begin{array}{c}3.104 \\
(1.519) \\
2.024\end{array}$ \\
\hline African American & $\begin{array}{c}(0.385) \\
4.867\end{array}$ & $\begin{array}{c}(0.399) \\
4.293\end{array}$ & $\begin{array}{l}(1.010) \\
10.309\end{array}$ \\
\hline Asian & $\begin{array}{c}(1.755) \\
0.938\end{array}$ & $\begin{array}{c}(1.845) \\
0.965\end{array}$ & $\begin{array}{c}(6.413) \\
0.744\end{array}$ \\
\hline Female & $\begin{array}{c}(0.088) \\
0.971\end{array}$ & $\begin{array}{c}(0.093) \\
0.953\end{array}$ & $\begin{array}{c}(0.193) \\
1.049\end{array}$ \\
\hline Age & $(0.009)$ & $(0.010)$ & $(0.026)$ \\
\hline Widowed & $\begin{array}{c}1.313 \\
(0.161)\end{array}$ & $\begin{array}{c}1.288 \\
(0.171)\end{array}$ & $\begin{array}{c}1.804 \\
(0.627)\end{array}$ \\
\hline \multicolumn{4}{|l|}{ Education (Some College or More Omitted) } \\
\hline No high school degree & $\begin{array}{c}1.240 \\
(0.171) \\
1.114\end{array}$ & $\begin{array}{c}1.307 \\
(0.188) \\
1.170\end{array}$ & $\begin{array}{c}1.115 \\
(0.348) \\
0.881\end{array}$ \\
\hline High school degree & $\begin{array}{c}(0.150) \\
1.000\end{array}$ & $\begin{array}{c}(0.171) \\
1.000\end{array}$ & $\begin{array}{c}(0.256) \\
1.000\end{array}$ \\
\hline Personal monthly income & $\begin{array}{c}(0.000) \\
0.829\end{array}$ & $\begin{array}{c}(0.000) \\
0.843\end{array}$ & $\begin{array}{c}(0.000) \\
0.624\end{array}$ \\
\hline Reports being in good health & $\begin{array}{c}(0.131) \\
0.823\end{array}$ & $\begin{array}{c}(0.140) \\
1.287\end{array}$ & $(0.213)$ \\
\hline Owns a home & $(0.130)$ & $(0.228)$ & -- \\
\hline \multicolumn{4}{|l|}{ Change over year } \\
\hline Became widowed & $\begin{array}{c}2.667 \\
(0.526)\end{array}$ & $\begin{array}{c}2.285 \\
(0.615)\end{array}$ & $\begin{array}{c}3.610 \\
(1.453)\end{array}$ \\
\hline \multicolumn{4}{|l|}{ Health (Had same health omitted) } \\
\hline $\begin{array}{l}\text { Had worse health } \\
\text { Had better health }\end{array}$ & $\begin{array}{c}1.262 \\
(0.257) \\
1.151 \\
(0.183)\end{array}$ & $\begin{array}{c}1.039 \\
(0.213) \\
1.267 \\
(0.213)\end{array}$ & $\begin{array}{c}1.899 \\
(0.793) \\
0.814 \\
(0.408)\end{array}$ \\
\hline \multicolumn{4}{|l|}{ Tenure (Had same tenure omitted) } \\
\hline Became homeowner & $\begin{array}{c}1.828 \\
(0.714)\end{array}$ & $\begin{array}{c}1.799 \\
(0.708)\end{array}$ & -- \\
\hline Became not a homeowner & $\begin{array}{c}5.115 \\
(1.158)\end{array}$ & --- & $\begin{array}{l}24.160 \\
(7.136)\end{array}$ \\
\hline Change in personal monthly income & $\begin{array}{c}0.997 \\
(0.003)\end{array}$ & $\begin{array}{c}0.998 \\
(0.002)\end{array}$ & $\begin{array}{c}0.760 \\
(0.228)\end{array}$ \\
\hline \multicolumn{4}{|l|}{ Panel (2008 omitted) } \\
\hline 1996 & $\begin{array}{c}0.930 \\
(0.153) \\
1.225\end{array}$ & $\begin{array}{c}0.866 \\
(0.159) \\
1.237\end{array}$ & $\begin{array}{c}1.149 \\
(0.545) \\
1.081\end{array}$ \\
\hline 2001 & $\begin{array}{c}(0.240) \\
1.055\end{array}$ & $\begin{array}{c}(0.267) \\
1.050\end{array}$ & $\begin{array}{c}(0.553) \\
1.073\end{array}$ \\
\hline Constant & $\begin{array}{c}(0.182) \\
0.076 \\
(0.059)\end{array}$ & $\begin{array}{c}(0.191) \\
0.181 \\
(0.149)\end{array}$ & $\begin{array}{c}(0.509) \\
0.000 \\
(0.000)\end{array}$ \\
\hline Observations & 29,150 & 29,150 & 29,150 \\
\hline Prob $>F$ & 0.000 & 0.000 & 0.000 \\
\hline
\end{tabular}

Source: Survey of Income and Program Participation, 1996 - 2008 panels

Note: $p<.01 ; p<.05 ; p<.10 ;$ standard errors in parentheses. Topical observations only. Population estimates reported.

Waves controlled but estimates suppressed. 
Table 6: Effect of Changes in Seniors' Assets \& Debt on Their Propensity of Forming a Multigenerational Household Over the Year

\begin{tabular}{|c|c|c|c|}
\hline Source & $\begin{array}{l}\text { Effect of Change } \\
\text { in Source on } \\
\text { Odds of } \\
\text { Forming a } \\
\text { Multigen } \\
\text { Household }\end{array}$ & $\begin{array}{l}\text { Effect of Change } \\
\text { in Source on } \\
\text { Odds of } \\
\text { Forming a } \\
\text { Multigen } \\
\text { Household as a } \\
\text { Household Head }\end{array}$ & $\begin{array}{c}\text { Effect of Change } \\
\text { in Source on } \\
\text { Odds of } \\
\text { Forming a } \\
\text { Multigen } \\
\text { Household as a } \\
\text { Non-Household } \\
\text { Head }\end{array}$ \\
\hline \multirow{2}{*}{ Net Worth } & 1.000 & 1.000 & 1.000 \\
\hline & $\begin{array}{c}(0.000) \\
0.968\end{array}$ & $\begin{array}{c}(0.001) \\
0.960\end{array}$ & $\begin{array}{c}(0.000) \\
0.950\end{array}$ \\
\hline Logged & $\begin{array}{c}(0.136) \\
1.044\end{array}$ & $\begin{array}{c}(0.139) \\
0.928\end{array}$ & $\begin{array}{c}(0.199) \\
2.174\end{array}$ \\
\hline Lost Value & $\begin{array}{c}(0.115) \\
1.000\end{array}$ & $\begin{array}{c}(0.111) \\
1.000\end{array}$ & $(0.652)$ \\
\hline Home Equity & $\begin{array}{c}(0.000) \\
1.136\end{array}$ & $\begin{array}{c}(0.000) \\
1.145\end{array}$ & -- \\
\hline Logged & $\begin{array}{c}(0.153) \\
1.289\end{array}$ & $\begin{array}{c}(0.152) \\
1.289\end{array}$ & -- \\
\hline Lost Value & $\begin{array}{c}(0.187) \\
1.000\end{array}$ & $\begin{array}{c}(0.187) \\
1.000\end{array}$ & 0.918 \\
\hline Interest Account & $\begin{array}{c}(0.000) \\
1.014\end{array}$ & $\begin{array}{c}(0.000) \\
1.061\end{array}$ & $\begin{array}{c}(0.050) \\
0.681\end{array}$ \\
\hline Logged & $\begin{array}{c}(0.048) \\
0.732\end{array}$ & $\begin{array}{c}(0.051) \\
0.648\end{array}$ & $\begin{array}{c}(0.131) \\
0.969\end{array}$ \\
\hline Lost Value & $\begin{array}{c}(0.101) \\
0.999\end{array}$ & $\begin{array}{c}(0.097) \\
0.999\end{array}$ & $\begin{array}{c}(0.331) \\
0.985\end{array}$ \\
\hline Life Insurance & $\begin{array}{c}(0.001) \\
1.008\end{array}$ & $\begin{array}{c}(0.001) \\
1.009\end{array}$ & $\begin{array}{c}(0.026) \\
1.040\end{array}$ \\
\hline Logged & $\begin{array}{c}(0.083) \\
1.240\end{array}$ & $\begin{array}{c}(0.090) \\
1.237\end{array}$ & $\begin{array}{c}(0.181) \\
1.052\end{array}$ \\
\hline Lost Value & $\begin{array}{c}(0.127) \\
0.994\end{array}$ & $\begin{array}{c}(0.133) \\
0.995\end{array}$ & $\begin{array}{c}(0.344) \\
0.992\end{array}$ \\
\hline Checking Account & $\begin{array}{c}(0.005) \\
1.049\end{array}$ & $\begin{array}{c}(0.005) \\
1.008\end{array}$ & $\begin{array}{c}(0.008) \\
1.198\end{array}$ \\
\hline Logged & $\begin{array}{c}(0.099) \\
0.908\end{array}$ & $\begin{array}{c}(0.101) \\
0.964\end{array}$ & $\begin{array}{c}(0.240) \\
0.700\end{array}$ \\
\hline Lost Value & $\begin{array}{c}(0.153) \\
1.000\end{array}$ & $\begin{array}{c}(0.179) \\
1.000\end{array}$ & $\begin{array}{c}(0.220) \\
0.723\end{array}$ \\
\hline IRA & $\begin{array}{c}(0.000) \\
1.008\end{array}$ & $\begin{array}{c}(0.000) \\
1.048\end{array}$ & $\begin{array}{c}(0.202) \\
0.553\end{array}$ \\
\hline Logged & $\begin{array}{c}(0.138) \\
0.844\end{array}$ & $\begin{array}{c}(0.133) \\
0.820\end{array}$ & $\begin{array}{c}(0.280) \\
0.700\end{array}$ \\
\hline Lost Value & $\begin{array}{c}(0.150) \\
0.975\end{array}$ & $\begin{array}{c}(0.142) \\
0.979\end{array}$ & $\begin{array}{c}(0.446) \\
0.775\end{array}$ \\
\hline Stocks & $\begin{array}{c}(0.025) \\
0.857\end{array}$ & $\begin{array}{c}(0.022) \\
0.877\end{array}$ & $\begin{array}{c}(0.088) \\
0.686\end{array}$ \\
\hline Logged & $\begin{array}{c}(0.104) \\
0.912\end{array}$ & $\begin{array}{c}(0.111) \\
0.972\end{array}$ & $\begin{array}{c}(0.135) \\
0.365\end{array}$ \\
\hline Lost Value & $\begin{array}{c}(0.194) \\
0.996\end{array}$ & $\begin{array}{c}(0.224) \\
0.997\end{array}$ & $\begin{array}{c}(0.241) \\
0.849\end{array}$ \\
\hline Credit Card Debt & $\begin{array}{c}(0.006) \\
0.824\end{array}$ & $\begin{array}{c}(0.004) \\
0.839\end{array}$ & $\begin{array}{c}(0.116) \\
0.752\end{array}$ \\
\hline Logged & $\begin{array}{l}(0.112) \\
1418\end{array}$ & $\begin{array}{l}(0.125) \\
1545\end{array}$ & $\begin{array}{c}(0.216) \\
0.797\end{array}$ \\
\hline Lost Value & $(0.214)$ & $(0.246)$ & $(0.283)$ \\
\hline
\end{tabular}

Source: Survey of Income and Program Participation, 1996 - 2008 panels

Note: $p<.01 ; p<.05 ; p<.10 ;$ standard errors in parentheses. Population estimates reported. Sources owned jointly and solely are combined. Composite variables like net worth, retirement income, and social welfare program participation contain many more sources than are disaggregated on the table; only sources reported by at least $10 \%$ of seniors were analyzed separately. Waves, panel years, and demographic and socioeconomic characteristics controlled but estimates suppressed. 
Table 7: Effect of Changes in Seniors' Retirement Income on Their Propensity of Forming a Multigenerational Household Over the Past Four Months

\begin{tabular}{|c|c|c|c|}
\hline Source & $\begin{array}{c}\text { Effect of Change } \\
\text { in Source on } \\
\text { Odds of } \\
\text { Forming a } \\
\text { Multigen } \\
\text { Household }\end{array}$ & $\begin{array}{l}\text { Effect of Change } \\
\text { in Source on } \\
\text { Odds of } \\
\text { Forming a } \\
\text { Multigen } \\
\text { Household as a } \\
\text { Household Head }\end{array}$ & $\begin{array}{l}\text { Effect of Change } \\
\text { in Source on } \\
\text { Odds of } \\
\text { Forming a } \\
\text { Multigen } \\
\text { Household as a } \\
\text { Non-Household } \\
\text { Head }\end{array}$ \\
\hline \multirow{2}{*}{ Retirement Income } & 0.998 & 0.999 & 0.990 \\
\hline & $\begin{array}{c}(0.005) \\
1.042\end{array}$ & $\begin{array}{c}(0.005) \\
1.069\end{array}$ & $\begin{array}{c}(0.018) \\
0.985\end{array}$ \\
\hline Logged & $\begin{array}{c}(0.121) \\
0.956\end{array}$ & $\begin{array}{c}(0.132) \\
1.023\end{array}$ & $\begin{array}{c}(0.386) \\
0.794\end{array}$ \\
\hline Lost Value & $\begin{array}{c}(0.062) \\
0.997\end{array}$ & $\begin{array}{c}(0.079) \\
0.997\end{array}$ & $\begin{array}{c}(0.125) \\
1.000\end{array}$ \\
\hline Social Security & $(0.002)$ & $(0.003)$ & $(0.002)$ \\
\hline \multirow{2}{*}{ Logged } & 0.924 & 0.939 & 1.011 \\
\hline & $(0.209)$ & $(0.236)$ & $(0.576)$ \\
\hline \multirow{2}{*}{ Lost Value } & 1.240 & 1.336 & 0.910 \\
\hline & $(0.103)$ & $(0.125)$ & $(0.199)$ \\
\hline \multirow{2}{*}{ Retirement Income Excluding Social Security } & 1.000 & 1.000 & 1.000 \\
\hline & $(0.001)$ & $(0.000)$ & $(0.007)$ \\
\hline \multirow{2}{*}{ Logged } & 0.999 & 1.030 & 0.884 \\
\hline & $(0.062)$ & $(0.069)$ & $(0.153)$ \\
\hline \multirow{2}{*}{ Lost Value } & 0.899 & 0.948 & 0.809 \\
\hline & $\begin{array}{c}(0.072) \\
1.003\end{array}$ & $\begin{array}{c}(0.086) \\
1.005\end{array}$ & $\begin{array}{c}(0.131) \\
0.988\end{array}$ \\
\hline Interest Payments & $\begin{array}{c}(0.004) \\
1.112\end{array}$ & $\begin{array}{c}(0.004) \\
1.125\end{array}$ & $\begin{array}{c}(0.015) \\
1.046\end{array}$ \\
\hline Logged & $(0.076)$ & $(0.094)$ & $(0.128)$ \\
\hline \multirow{2}{*}{ Lost Value } & 0.752 & 0.848 & 0.492 \\
\hline & $\begin{array}{c}(0.069) \\
1.000\end{array}$ & $\begin{array}{c}(0.086) \\
1.003\end{array}$ & $\begin{array}{c}(0.098) \\
0.613\end{array}$ \\
\hline Pension & $\begin{array}{c}(0.008) \\
0.911\end{array}$ & $\begin{array}{c}(0.003) \\
1.155\end{array}$ & $\begin{array}{c}(0.219) \\
0.329\end{array}$ \\
\hline Logged & $(0.196)$ & $(0.239)$ & $(0.171)$ \\
\hline \multirow{2}{*}{ Lost Value } & 1.396 & 1.350 & 1.807 \\
\hline & (0.162) & $(0.185)$ & (0.389) \\
\hline
\end{tabular}

Source: Survey of Income and Program Participation, 1996 - 2008 panels

Note: $p<.01 ; p<.05 ; p<.10 ;$ standard errors in parentheses. Population estimates reported. Sources owned jointly and solely are combined. Composite variables like net worth, retirement income, and social welfare program participation contain many more sources than are disaggregated on the table; only sources reported by at least $10 \%$ of seniors were analyzed separately. Waves, panel years, and demographic and socioeconomic characteristics controlled but estimates suppressed. 
Table 8: Effect of Seniors' Enrollment in a Social Welfare Program on Their Propensity of Forming a Multigenerational Household Over the Past Four Months

\begin{tabular}{|c|c|c|c|}
\hline Source & $\begin{array}{l}\text { Effect of Change } \\
\text { in Source on } \\
\text { Odds of } \\
\text { Forming a } \\
\text { Multigen } \\
\text { Household }\end{array}$ & $\begin{array}{l}\text { Effect of Change } \\
\text { in Source on } \\
\text { Odds of } \\
\text { Forming a } \\
\text { Multigen } \\
\text { Household as a } \\
\text { Household Head }\end{array}$ & $\begin{array}{l}\text { Effect of Change } \\
\text { in Source on } \\
\text { Odds of } \\
\text { Forming a } \\
\text { Multigen } \\
\text { Household as a } \\
\text { Non-Household } \\
\text { Head }\end{array}$ \\
\hline \multirow{2}{*}{ Social Welfare Program } & 1.624 & 1.907 & 0.473 \\
\hline & $\begin{array}{c}(0.544) \\
1.908\end{array}$ & $\begin{array}{c}(0.665) \\
2.209\end{array}$ & $\begin{array}{c}(0.478) \\
0.927\end{array}$ \\
\hline Medicare & $\begin{array}{c}1.908 \\
(0.565)\end{array}$ & $\begin{array}{c}2.209 \\
(0.697)\end{array}$ & $(0.673)$ \\
\hline \multirow{2}{*}{ Social Welfare Program Excluding Medicare } & 1.491 & 1.534 & 1.371 \\
\hline & $(0.309)$ & $(0.355)$ & (0.572) \\
\hline Medicaid & 1.211 & 1.431 & 0.559 \\
\hline
\end{tabular}

Source: Survey of Income and Program Participation, 1996 - 2008 panels

Note: $p<.01 ; p<.05 ; p<.10 ;$ standard errors in parentheses. Population estimates reported. Sources owned jointly and solely are combined. Composite variables like net worth, retirement income, and social welfare program participation contain many more sources than are disaggregated on the table; only sources reported by at least $10 \%$ of seniors were analyzed separately. Waves, panel years, and demographic and socioeconomic characteristics controlled but estimates suppressed. 


\begin{tabular}{|c|c|c|c|c|c|c|c|c|}
\hline \multirow[t]{2}{*}{ Source } & \multicolumn{2}{|c|}{$\begin{array}{l}\text { Effect of Living in a Multigen } \\
\text { Household on Source, All Seniors }\end{array}$} & \multicolumn{2}{|c|}{$\begin{array}{l}\text { Effect of Living as a Non- } \\
\text { Household Head in a Multigen } \\
\text { Household on Source, Seniors in } \\
\text { Multigen Households }\end{array}$} & \multicolumn{2}{|c|}{$\begin{array}{c}\text { Effect of Living in a Multigen } \\
\text { Household on Source, Household } \\
\text { Head Seniors }\end{array}$} & \multicolumn{2}{|c|}{$\begin{array}{l}\text { Effect of Living in a Multigen } \\
\text { Household on Source, Non- } \\
\text { Household Head Seniors }\end{array}$} \\
\hline & $\begin{array}{l}\text { Household } \\
\text { Persons Not } \\
\text { Controlled }\end{array}$ & $\begin{array}{l}\text { Household } \\
\text { Persons } \\
\text { Controlled }\end{array}$ & $\begin{array}{l}\text { Household } \\
\text { Persons Not } \\
\text { Controlled }\end{array}$ & $\begin{array}{l}\text { Household } \\
\text { Persons } \\
\text { Controlled }\end{array}$ & $\begin{array}{l}\text { Household } \\
\text { Persons Not } \\
\text { Controlled }\end{array}$ & $\begin{array}{l}\text { Household } \\
\text { Persons } \\
\text { Controlled }\end{array}$ & $\begin{array}{l}\text { Household } \\
\text { Persons Not } \\
\text { Controlled }\end{array}$ & $\begin{array}{l}\text { Household } \\
\text { Persons } \\
\text { Controlled }\end{array}$ \\
\hline Net Worth & $\$ 13,112$ & $\$ 324$ & $-\$ 80,962$ & $-\$ 85,091$ & $\$ 11,866$ & $-\$ 1,586$ & $\$ 21,124$ & $\$ 18,676$ \\
\hline & $\begin{array}{c}(\$ 11,831) \\
0.003\end{array}$ & $\begin{array}{c}(\$ 20,595) \\
-0.010\end{array}$ & $\begin{array}{c}(\$ 14,407) \\
-0.041\end{array}$ & $\begin{array}{c}(\$ 14,547) \\
-0.043\end{array}$ & $\begin{array}{c}(\$ 13,779) \\
0.006\end{array}$ & $\begin{array}{c}(\$ 26,567) \\
-0.011\end{array}$ & $\begin{array}{c}(\$ 11,673) \\
0.005\end{array}$ & $(\$ 12,722)$ \\
\hline Logged & $(0.002)$ & $(0.003)$ & $(0.004)$ & $(0.004)$ & $(0.003)$ & $(0.004)$ & $(0.003)$ & $(0.004)$ \\
\hline Zero or Negative Value & $\begin{array}{c}0.841 \\
(0.044)\end{array}$ & $\begin{array}{c}1.144 \\
(0.102)\end{array}$ & $\begin{array}{c}0.955 \\
(0.106)\end{array}$ & $\begin{array}{c}1.027 \\
(0.117)\end{array}$ & $\begin{array}{c}0.981 \\
(0.084)\end{array}$ & $\begin{array}{c}1.516 \\
(0.168)\end{array}$ & $\begin{array}{c}0.829 \\
(0.096)\end{array}$ & $\begin{array}{c}0.845 \\
(0.116)\end{array}$ \\
\hline Home Equity & & & & & $\begin{array}{c}\$ 24,596 \\
(\$ 3,599) \\
0.014\end{array}$ & $\begin{array}{c}-\$ 1,260 \\
(\$ 5,140) \\
0.000\end{array}$ & & \\
\hline 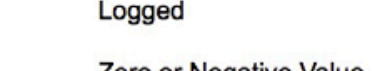 & & & & & $\begin{array}{c}(0.002) \\
0.537\end{array}$ & $\begin{array}{c}(0.003) \\
1.029\end{array}$ & & \\
\hline Zero or Negative Value & & & & & $(0.046)$ & $(0.128)$ & & \\
\hline Interest Account & $\begin{array}{l}-\$ 3,386 \\
(\$ 447) \\
-0.776\end{array}$ & $\begin{array}{l}-\$ 2,634 \\
(\$ 592) \\
-0.695\end{array}$ & $\begin{array}{c}\$ 85 \\
(\$ 785) \\
-0.247\end{array}$ & $\begin{array}{l}\$ 516 \\
(\$ 788) \\
-0.183\end{array}$ & $\begin{array}{l}-\$ 3,883 \\
(\$ 523) \\
-0.728\end{array}$ & $\begin{array}{l}-\$ 2,927 \\
(\$ 661) \\
-0.796\end{array}$ & $\begin{array}{c}-\$ 420 \\
(\$ 1,070) \\
-0.059\end{array}$ & $\begin{array}{c}\$ 132 \\
(\$ 1,183) \\
0.102\end{array}$ \\
\hline Logged & $\begin{array}{c}(0.061) \\
1.477\end{array}$ & $\begin{array}{c}(0.076) \\
1.431\end{array}$ & $\begin{array}{c}(0.136) \\
1.195\end{array}$ & $\begin{array}{c}(0.135) \\
1.161\end{array}$ & $\begin{array}{c}(0.071) \\
1.416\end{array}$ & $\begin{array}{c}(0.090) \\
1.520\end{array}$ & $\begin{array}{c}(0.181) \\
1.065\end{array}$ & $\begin{array}{c}(0.191) \\
0.972\end{array}$ \\
\hline Zero Value & $\begin{array}{l}(0.048) \\
\$ 5,065\end{array}$ & $\begin{array}{l}(0.060) \\
-\$ 1,022\end{array}$ & $\begin{array}{l}(0.091) \\
\$ 8,790\end{array}$ & $\begin{array}{l}(0.087) \\
\$ 7,977\end{array}$ & $\begin{array}{l}(0.056) \\
\$ 2,519\end{array}$ & $\begin{array}{l}(0.078) \\
-\$ 4,185\end{array}$ & $\begin{array}{l}(0.110) \\
\$ 6,474\end{array}$ & $\begin{array}{l}(0.103) \\
\$ 4,734\end{array}$ \\
\hline Life Insurance & $\begin{array}{c}(\$ 828) \\
0.291\end{array}$ & $\begin{array}{c}(\$ 1,322) \\
0.106\end{array}$ & $\begin{array}{c}(\$ 2,343) \\
-0.026\end{array}$ & $\begin{array}{c}(\$ 2,370) \\
-0.038\end{array}$ & $\begin{array}{l}(\$ 917) \\
0.271\end{array}$ & $\begin{array}{c}(\$ 1,472) \\
-0.066\end{array}$ & $\begin{array}{c}(\$ 3,082) \\
0.557\end{array}$ & $\begin{array}{c}(\$ 3,318) \\
0.584\end{array}$ \\
\hline Logged & $\begin{array}{c}(0.074) \\
0.914\end{array}$ & $\begin{array}{c}(0.097) \\
0.961\end{array}$ & $\begin{array}{c}(0.137) \\
1.082\end{array}$ & $\begin{array}{c}(0.142) \\
1.080\end{array}$ & $\begin{array}{c}(0.087) \\
0.905\end{array}$ & $\begin{array}{c}(0.109) \\
1.029\end{array}$ & $\begin{array}{c}(0.181) \\
0.779\end{array}$ & $\begin{array}{c}(0.198) \\
0.748\end{array}$ \\
\hline Zero Value & $\begin{array}{l}(0.031) \\
-\$ 28\end{array}$ & $\begin{array}{c}(0.041) \\
-\$ 1\end{array}$ & $\begin{array}{l}(0.070) \\
-\$ 24\end{array}$ & $\begin{array}{c}(0.072) \\
-\$ 36\end{array}$ & $\begin{array}{l}(0.035) \\
-\$ 19\end{array}$ & $\begin{array}{c}(0.048) \\
\$ 20\end{array}$ & $\begin{array}{c}(0.067) \\
\$ 52\end{array}$ & $\begin{array}{c}(0.070) \\
\$ 22\end{array}$ \\
\hline Checking Account & $\begin{array}{l}(\$ 17) \\
-0.125\end{array}$ & $\begin{array}{c}(\$ 22) \\
-0.029\end{array}$ & $\begin{array}{c}(\$ 34) \\
-0.312\end{array}$ & $\begin{array}{c}(\$ 34) \\
-0.318\end{array}$ & $\begin{array}{l}(\$ 21) \\
-0.003\end{array}$ & $\begin{array}{l}(\$ 26) \\
0.038\end{array}$ & $\begin{array}{l}(\$ 57) \\
0.040\end{array}$ & $\begin{array}{l}(\$ 59) \\
0.010\end{array}$ \\
\hline Logged & $\begin{array}{c}(0.038) \\
1.142\end{array}$ & $\begin{array}{c}(0.051) \\
1.026\end{array}$ & $\begin{array}{c}(0.086) \\
1.513\end{array}$ & $\begin{array}{c}(0.086) \\
1.511\end{array}$ & $\begin{array}{c}(0.046) \\
0.996\end{array}$ & $\begin{array}{c}(0.059) \\
0.969\end{array}$ & $\begin{array}{c}(0.105) \\
1.013\end{array}$ & $\begin{array}{c}(0.112) \\
1.013\end{array}$ \\
\hline Zero Value & $\begin{array}{l}(0.039) \\
-\$ 3,496\end{array}$ & $\begin{array}{r}(0.045) \\
-\$ 3,903\end{array}$ & $\begin{array}{l}(0.130) \\
\$ 1,049\end{array}$ & $\begin{array}{l}(0,131) \\
\$ 1,403\end{array}$ & $\begin{array}{l}(0.039) \\
\$-5,478\end{array}$ & $\begin{array}{l}(0.048) \\
-\$ 5,060\end{array}$ & $\begin{array}{c}(0.105) \\
\$ 185\end{array}$ & $\begin{array}{c}(0.112) \\
\$ 329\end{array}$ \\
\hline IRA & $\begin{array}{l}(\$ 575) \\
-0.441\end{array}$ & $\begin{array}{l}(\$ 830) \\
-0.409\end{array}$ & $\begin{array}{c}(\$ 1,107) \\
-0.051\end{array}$ & $\begin{array}{c}(\$ 1,113) \\
-0.016\end{array}$ & $\begin{array}{l}(\$ 737) \\
-0.585\end{array}$ & $\begin{array}{c}(\$ 1,019) \\
-0.461\end{array}$ & $\begin{array}{c}(\$ 1,504) \\
-0.046\end{array}$ & $\begin{array}{c}(\$ 1,403) \\
-0.039\end{array}$ \\
\hline Logged & $\begin{array}{l}(0.055) \\
1.524\end{array}$ & $\begin{array}{c}(0.077) \\
1.319\end{array}$ & $\begin{array}{c}(0.098) \\
1.172\end{array}$ & $\begin{array}{c}(0.096) \\
1.127\end{array}$ & $\begin{array}{c}(0.072) \\
1.485\end{array}$ & $\begin{array}{c}(0.091) \\
1.308\end{array}$ & $\begin{array}{c}(0.126) \\
0.995\end{array}$ & $\begin{array}{c}(0.130) \\
1.002\end{array}$ \\
\hline Zero Value & $\begin{array}{l}(0.080) \\
\$ 9,772\end{array}$ & $\begin{array}{l}(0.090) \\
\$ 21,057\end{array}$ & $\begin{array}{l}(0.178) \\
-\$ 2,679\end{array}$ & $\begin{array}{l}(0.165) \\
-\$ 2,113\end{array}$ & $\begin{array}{l}(0.085) \\
\$ 2,438\end{array}$ & $\begin{array}{l}(0.091) \\
\$ 22,621\end{array}$ & $\begin{array}{l}(0.192) \\
\$ 9,882\end{array}$ & $\begin{array}{l}(0.207) \\
\$ 9,525\end{array}$ \\
\hline Stocks & $\begin{array}{c}(\$ 10,435) \\
-0.398\end{array}$ & $\begin{array}{c}(\$ 18,803) \\
-0.773\end{array}$ & $\begin{array}{c}(\$ 11,286) \\
-0.088\end{array}$ & $\begin{array}{c}(\$ 11,225) \\
-0.106\end{array}$ & $\begin{array}{c}(\$ 11,603) \\
-0.500\end{array}$ & $\begin{array}{c}(\$ 24,268) \\
-0.935\end{array}$ & $\begin{array}{c}(\$ 9,073) \\
-0.129\end{array}$ & $\begin{array}{c}(\$ 9,943) \\
-0.181\end{array}$ \\
\hline Logged & $\begin{array}{c}(0.055) \\
1.524\end{array}$ & $\begin{array}{c}(0.071) \\
1.964\end{array}$ & $\begin{array}{c}(0.099) \\
1.141\end{array}$ & $\begin{array}{c}(0.101) \\
1.164\end{array}$ & $\begin{array}{c}(0.070) \\
1.486\end{array}$ & $\begin{array}{c}(0.091) \\
2.037\end{array}$ & $\begin{array}{c}(0.124) \\
1.199\end{array}$ & $\begin{array}{c}(0.126) \\
1.304\end{array}$ \\
\hline Zero Value & $\begin{array}{c}(0.077) \\
\$ 254\end{array}$ & $\begin{array}{c}(0.121) \\
\$ 292\end{array}$ & $\begin{array}{l}(0.182) \\
-\$ 201\end{array}$ & $\begin{array}{c}(0.190) \\
-\$ 196\end{array}$ & $\begin{array}{c}(0.085) \\
\$ 367\end{array}$ & $\begin{array}{c}(0.144) \\
\$ 333\end{array}$ & $\begin{array}{c}(0.248) \\
-\$ 158\end{array}$ & $\begin{array}{l}(0.276) \\
-\$ 106\end{array}$ \\
\hline Credit Card Debt & $\begin{array}{l}(\$ 52) \\
0.249\end{array}$ & $\begin{array}{l}(\$ 74) \\
0.250\end{array}$ & $\begin{array}{l}(\$ 113) \\
-0.412\end{array}$ & $\begin{array}{l}(\$ 114) \\
-0.400\end{array}$ & $\begin{array}{l}(\$ 63) \\
0.418\end{array}$ & $\begin{array}{l}(\$ 86) \\
0.267\end{array}$ & $\begin{array}{c}(\$ 234) \\
0.155\end{array}$ & $\begin{array}{c}(\$ 237) \\
0.172\end{array}$ \\
\hline Logged & $\begin{array}{c}(0.044) \\
0.855\end{array}$ & $\begin{array}{c}(0.062) \\
0.866\end{array}$ & $\begin{array}{c}(0.104) \\
1.544\end{array}$ & $\begin{array}{c}(0.106) \\
1.530\end{array}$ & $\begin{array}{c}(0.055) \\
0.759\end{array}$ & $\begin{array}{c}(0.073) \\
0.854\end{array}$ & $\begin{array}{c}(0.133) \\
0.835\end{array}$ & $\begin{array}{c}(0.145) \\
0.833\end{array}$ \\
\hline Zero Value & $(0.030)$ & $(0.041)$ & $(0.142)$ & $(0.143)$ & $(0.030)$ & $(0.043)$ & $(0.116)$ & $(0.127)$ \\
\hline
\end{tabular}

Source: Survey of Income and Program Participation, 1996 - 2008 panels

Note: $p<.01 ; p<.05 ; p<.10 ;$ standard errors in parentheses. Population estimates reported. Sources owned jointly and solely are combined. Composite variables like net worth, retirement income, and social welfare program participation contain

many more sources than are disaggregated on the table; only sources reported by at least $10 \%$ of seniors were analyzed separately. Waves, panel years, and demographic and socioeconomic characteristics are controlled but estimates are suppressed. 


\begin{tabular}{|c|c|c|c|c|c|c|c|c|}
\hline \multirow{2}{*}{ Source } & \multicolumn{2}{|c|}{$\begin{array}{l}\text { Effect of Living in a Multigen } \\
\text { Household on Source, All Seniors }\end{array}$} & \multicolumn{2}{|c|}{$\begin{array}{l}\text { Effect of Living as a Non- } \\
\text { Household Head in a Multigen } \\
\text { Household on Source, Seniors in } \\
\text { Multigen Households }\end{array}$} & \multicolumn{2}{|c|}{$\begin{array}{c}\text { Effect of Living in a Multigen } \\
\text { Household on Source, Household } \\
\text { Head Seniors }\end{array}$} & \multicolumn{2}{|c|}{$\begin{array}{c}\text { Effect of Living in a Multigen } \\
\text { Household on Source, Non- } \\
\text { Household Head Seniors }\end{array}$} \\
\hline & $\begin{array}{l}\text { Household } \\
\text { Persons Not } \\
\text { Controlled }\end{array}$ & $\begin{array}{l}\text { Household } \\
\text { Persons } \\
\text { Controlled }\end{array}$ & $\begin{array}{l}\text { Household } \\
\text { Persons Not } \\
\text { Controlled }\end{array}$ & $\begin{array}{l}\text { Household } \\
\text { Persons } \\
\text { Controlled }\end{array}$ & $\begin{array}{l}\text { Household } \\
\text { Persons Not } \\
\text { Controlled }\end{array}$ & $\begin{array}{l}\text { Household } \\
\text { Persons } \\
\text { Controlled }\end{array}$ & $\begin{array}{l}\text { Household } \\
\text { Persons Not } \\
\text { Controlled }\end{array}$ & $\begin{array}{l}\text { Household } \\
\text { Persons } \\
\text { Controlled }\end{array}$ \\
\hline \multirow{2}{*}{ Retirement Income } & $-\$ 147$ & $-\$ 44$ & $-\$ 236$ & $-\$ 219$ & $-\$ 85$ & $-\$ 12$ & $-\$ 37$ & $-\$ 29$ \\
\hline & $\begin{array}{c}(\$ 23) \\
-0.263\end{array}$ & $\begin{array}{c}(\$ 29) \\
-0.012\end{array}$ & $\begin{array}{c}(\$ 28) \\
-0.722\end{array}$ & $\begin{array}{c}(\$ 28) \\
-0.657\end{array}$ & $\begin{array}{c}(\$ 32) \\
-0.037\end{array}$ & $\begin{array}{l}(\$ 36) \\
0.025\end{array}$ & $\begin{array}{c}(\$ 45) \\
-0.214\end{array}$ & $\begin{array}{c}(\$ 46) \\
-0.069\end{array}$ \\
\hline Logged & $(0.022)$ & $(0.029)$ & $(0.054)$ & $(0.051)$ & $(0.021)$ & $(0.029)$ & $(0.096)$ & $(0.094)$ \\
\hline \multirow{2}{*}{ Zero Value } & 2.111 & 1.520 & 3.175 & 3.023 & 1.069 & 1.178 & 0.962 & 0.856 \\
\hline & $(0.132)$ & $(0.103)$ & $(0.381)$ & $(0.362)$ & $(0.087)$ & $(0.131)$ & $(0.153)$ & $(0.135)$ \\
\hline \multirow{2}{*}{ Social Security } & $-\$ 36$ & $\$ 27$ & $-\$ 101$ & $-\$ 89$ & $-\$ 1$ & $\$ 47$ & $-\$ 25$ & $-\$ 8$ \\
\hline & $(\$ 7)$ & $(\$ 9)$ & $(\$ 13)$ & (\$12) & $(\$ 8)$ & $(\$ 10)$ & $(\$ 25)$ & $(\$ 26)$ \\
\hline \multirow{2}{*}{ Logged } & -0.247 & -0.006 & -0.651 & -0.590 & -0.043 & 0.018 & -0.188 & -0.037 \\
\hline & $\begin{array}{c}(0.026) \\
1.625\end{array}$ & $\begin{array}{c}(0.036) \\
1.245\end{array}$ & $\begin{array}{c}(0.059) \\
2.554\end{array}$ & $\begin{array}{c}(0.056) \\
2.414\end{array}$ & $\begin{array}{c}(0.027) \\
1.108\end{array}$ & $\begin{array}{c}(0.036) \\
1.118\end{array}$ & $\begin{array}{c}(0.103) \\
1.080\end{array}$ & $\begin{array}{c}(0.101) \\
0.942\end{array}$ \\
\hline Zero Value & $(0.074)$ & $(0.074)$ & $(0.230)$ & $(0.211)$ & $(0.066)$ & $(0.085)$ & $(0.157)$ & $(0.131)$ \\
\hline \multirow{2}{*}{ Retirement Income Excluding Social Security } & $-\$ 101$ & $-\$ 80$ & $-\$ 108$ & $-\$ 106$ & $-\$ 85$ & $-\$ 74$ & $-\$ 8$ & $-\$ 18$ \\
\hline & $(\$ 22)$ & $(\$ 27)$ & $(\$ 21)$ & $(\$ 22)$ & $(\$ 31)$ & $(\$ 35)$ & $(\$ 38)$ & $(\$ 39)$ \\
\hline \multirow{2}{*}{ Logged } & -0.410 & -0.206 & -0.755 & -0.708 & -0.158 & -0.136 & -0.022 & 0.062 \\
\hline & $(0.038)$ & $(0.050)$ & $(0.072)$ & $(0.074)$ & $(0.045)$ & $(0.060)$ & $(0.131)$ & $(0.133)$ \\
\hline \multirow{2}{*}{ Zero Value } & 1.422 & 1.263 & 1.744 & 1.693 & 1.160 & 1.257 & 0.857 & 0.784 \\
\hline & $(.041)$ & $(0.048)$ & $(0.096)$ & $(0.095)$ & $(0.040)$ & $(0.058)$ & $(0.083)$ & $(0.080)$ \\
\hline \multirow{2}{*}{ Interest Payments } & $-\$ 17$ & $-\$ 15$ & $-\$ 5$ & $-\$ 3$ & $-\$ 16$ & $-\$ 16$ & $-\$ 2$ & $\$ 1$ \\
\hline & $(\$ 1)$ & $(\$ 2)$ & $(\$ 2)$ & $(\$ 2)$ & $(\$ 1)$ & $(\$ 2)$ & $(\$ 4)$ & $(\$ 4)$ \\
\hline \multirow{2}{*}{ Logged } & -0.420 & -0.395 & -0.337 & -0.310 & -0.319 & -0.402 & -0.050 & -0.004 \\
\hline & $(0.022)$ & $(0.028)$ & $(0.040)$ & $(0.040)$ & $(0.026)$ & $(0.033)$ & $(0.062)$ & $(0.063)$ \\
\hline \multirow{2}{*}{ Zero Value } & 1.601 & 1.521 & 1.778 & 1.706 & 1.378 & 1.549 & 0.993 & 0.895 \\
\hline & $(0.046)$ & $(0.057)$ & $(0.113)$ & $(0.107)$ & $(0.048)$ & $(0.067)$ & $(0.097)$ & $(0.090)$ \\
\hline \multirow{2}{*}{ Pension } & $-\$ 18$ & $-\$ 4$ & $-\$ 66$ & $-\$ 65$ & $\$ 4$ & $\$ 9$ & $-\$ 23$ & $-\$ 25$ \\
\hline & $(\$ 11)$ & $(\$ 16)$ & $(\$ 17)$ & $(\$ 18)$ & $(\$ 14)$ & $(\$ 18)$ & (\$34) & $(\$ 35)$ \\
\hline \multirow{2}{*}{ Logged } & -0.150 & 0.062 & -0.456 & -0.423 & 0.012 & 0.146 & -0.003 & 0.035 \\
\hline & $(0.044)$ & $(0.057)$ & $(0.072)$ & $(0.075)$ & $(0.051)$ & $(0.066)$ & $(0.137)$ & $(0.134)$ \\
\hline \multirow{2}{*}{ Zero Value } & 1.110 & 0.947 & 1.356 & 1.317 & 0.998 & 0.909 & 0.950 & 0.908 \\
\hline & $(0.035)$ & $(0.039)$ & $(0.077)$ & $(0.078)$ & $(0.034)$ & $(0.041)$ & $(0.108)$ & (0.099) \\
\hline
\end{tabular}

Source: Survey of Income and Program Participation, 1996 - 2008 panels

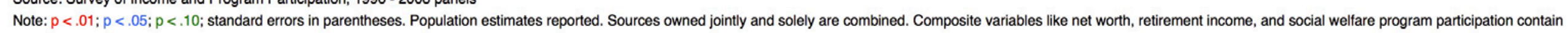

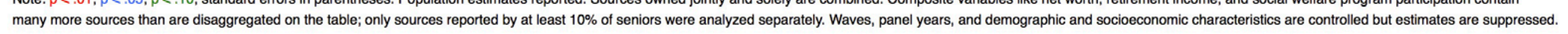




\begin{tabular}{|c|c|c|c|c|c|c|c|c|}
\hline \multirow{2}{*}{ Source } & \multicolumn{2}{|c|}{$\begin{array}{l}\text { Effect of Living in a Multigen } \\
\text { Household on Source, All Seniors }\end{array}$} & \multicolumn{2}{|c|}{$\begin{array}{l}\text { Effect of Living as a Non- } \\
\text { Household Head in a Multigen } \\
\text { Household on Source, Seniors in } \\
\text { Multigen Households }\end{array}$} & \multicolumn{2}{|c|}{$\begin{array}{c}\text { Effect of Living in a Multigen } \\
\text { Household on Source, Household } \\
\text { Head Seniors }\end{array}$} & \multicolumn{2}{|c|}{$\begin{array}{l}\text { Effect of Living in a Multigen } \\
\text { Household on Source, Non- } \\
\text { Household Head Seniors }\end{array}$} \\
\hline & $\begin{array}{l}\text { Household } \\
\text { Persons Not } \\
\text { Controlled }\end{array}$ & $\begin{array}{l}\text { Household } \\
\text { Persons } \\
\text { Controlled }\end{array}$ & $\begin{array}{l}\text { Household } \\
\text { Persons Not } \\
\text { Controlled }\end{array}$ & $\begin{array}{l}\text { Household } \\
\text { Persons } \\
\text { Controlled }\end{array}$ & $\begin{array}{l}\text { Household } \\
\text { Persons Not } \\
\text { Controlled }\end{array}$ & $\begin{array}{l}\text { Household } \\
\text { Persons } \\
\text { Controlled }\end{array}$ & $\begin{array}{l}\text { Household } \\
\text { Persons Not } \\
\text { Controlled }\end{array}$ & $\begin{array}{l}\text { Household } \\
\text { Persons } \\
\text { Controlled }\end{array}$ \\
\hline \multirow{2}{*}{ Social Welfare Program } & 0.550 & 0.752 & 0.301 & 0.319 & 0.844 & 0.842 & 0.603 & 0.723 \\
\hline & $\begin{array}{c}(0.044) \\
0.524\end{array}$ & $\begin{array}{c}(0.087) \\
0.702\end{array}$ & $\begin{array}{c}(0.044) \\
0.274\end{array}$ & $\begin{array}{c}(0.049) \\
0.291\end{array}$ & $\begin{array}{c}(0.084) \\
0.908\end{array}$ & $\begin{array}{c}(0.101) \\
0.822\end{array}$ & $\begin{array}{c}(0.141) \\
0.717\end{array}$ & $\begin{array}{c}(0.192) \\
0.833\end{array}$ \\
\hline Medicare & $\begin{array}{c}(0.032) \\
0.968\end{array}$ & $\begin{array}{c}(0.060) \\
1.298\end{array}$ & $\begin{array}{c}(0.031) \\
1.619\end{array}$ & $\begin{array}{c}(0.033) \\
1.639\end{array}$ & $\begin{array}{c}(0.075) \\
0.811\end{array}$ & $\begin{array}{c}(0.090) \\
1.469\end{array}$ & $\begin{array}{c}(0.132) \\
0.983\end{array}$ & $\begin{array}{c}(0.156) \\
1.026\end{array}$ \\
\hline Social Welfare Program Excluding Medicare & $\begin{array}{c}(0.034) \\
1.197\end{array}$ & $\begin{array}{c}(0.059) \\
1.495\end{array}$ & $\begin{array}{c}(0.106) \\
1.705\end{array}$ & $\begin{array}{c}(0.108) \\
1.728\end{array}$ & $\begin{array}{c}(0.034) \\
0.961\end{array}$ & $\begin{array}{c}(0.088) \\
1.590\end{array}$ & $\begin{array}{c}(0.112) \\
1.022\end{array}$ & $\begin{array}{c}(0.122) \\
1.057\end{array}$ \\
\hline 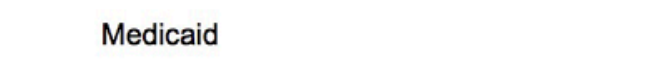 & $(0.050)$ & $(0.079)$ & $(0.125)$ & $(0.127)$ & $(0.049)$ & $(0.115)$ & $(0.124)$ & $(0.132)$ \\
\hline
\end{tabular}

Source: Survey of Income and Program Participation, 1996 - 2008 panels

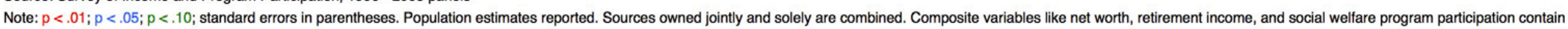

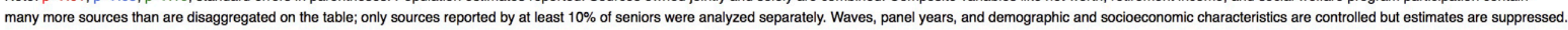




\section{Table 12: Effect of Living in a Multigenerational Household on Seniors' Propensity of Losing Assets \& Debt Over the Year, Controlling and Not Controlling for Total Household}

Persons

\begin{tabular}{|c|c|c|c|c|c|c|c|c|}
\hline \multirow[t]{2}{*}{ Source } & \multicolumn{2}{|c|}{$\begin{array}{c}\text { Effect of Living in a Multigen } \\
\text { Household on Change in Source, } \\
\text { All Seniors }\end{array}$} & \multicolumn{2}{|c|}{$\begin{array}{l}\text { Effect of Living as a Non- } \\
\text { Household Head in a Multigen } \\
\text { Household on Change in Source, } \\
\text { Seniors in Multigen Households }\end{array}$} & \multicolumn{2}{|c|}{$\begin{array}{l}\text { Effect of Living in a Multigen } \\
\text { Household on Change in Source, } \\
\text { Household Head Seniors }\end{array}$} & \multicolumn{2}{|c|}{$\begin{array}{l}\text { Effect of Living in a Multigen } \\
\text { Household on Change in Source } \\
\text { Non-Household Head Seniors }\end{array}$} \\
\hline & $\begin{array}{l}\text { Household } \\
\text { Persons Not } \\
\text { Controlled }\end{array}$ & $\begin{array}{l}\text { Household } \\
\text { Persons } \\
\text { Controlled }\end{array}$ & $\begin{array}{l}\text { Household } \\
\text { Persons Not } \\
\text { Controlled }\end{array}$ & $\begin{array}{l}\text { Household } \\
\text { Persons } \\
\text { Controlled }\end{array}$ & $\begin{array}{l}\text { Household } \\
\text { Persons Not } \\
\text { Controlled }\end{array}$ & $\begin{array}{l}\text { Household } \\
\text { Persons } \\
\text { Controlled }\end{array}$ & $\begin{array}{l}\text { Household } \\
\text { Persons Not } \\
\text { Controlled }\end{array}$ & $\begin{array}{l}\text { Household } \\
\text { Persons } \\
\text { Controlled }\end{array}$ \\
\hline Net Worth & $\begin{array}{c}1.017 \\
(0.038)\end{array}$ & $\begin{array}{c}0.931 \\
(0.044)\end{array}$ & $\begin{array}{c}1.315 \\
(0.116)\end{array}$ & $\begin{array}{c}1.295 \\
(0.117)\end{array}$ & $\begin{array}{c}0.923 \\
(0.040) \\
0.940\end{array}$ & $\begin{array}{c}0.877 \\
(0.051) \\
0.857\end{array}$ & $\begin{array}{c}1.242 \\
(0.172)\end{array}$ & $\begin{array}{c}1.192 \\
(0.166)\end{array}$ \\
\hline Interest Account & $\begin{array}{c}0.803 \\
(0.032) \\
1.140\end{array}$ & $\begin{array}{c}0.826 \\
(0.044) \\
1.062\end{array}$ & $\begin{array}{c}0.823 \\
(0.093) \\
1.166\end{array}$ & $\begin{array}{c}0.819 \\
(0.093) \\
1.164\end{array}$ & $\begin{array}{c}(0.048) \\
0.854 \\
(0.043) \\
1.059\end{array}$ & $\begin{array}{c}(0.059) \\
0.820 \\
(0.053) \\
0.973\end{array}$ & $\begin{array}{c}0.797 \\
(0.114) \\
1.773\end{array}$ & $\begin{array}{c}0.830 \\
(0.131) \\
1.728\end{array}$ \\
\hline Life Insurance & $\begin{array}{c}(0.044) \\
0.932\end{array}$ & $\begin{array}{c}(0.057) \\
0.967\end{array}$ & $\begin{array}{c}(0.110) \\
0.857\end{array}$ & $\begin{array}{c}(0.113) \\
0.846\end{array}$ & $\begin{array}{c}(0.045) \\
1.000\end{array}$ & $\begin{array}{c}(0.059) \\
1.039\end{array}$ & $\begin{array}{c}(0.238) \\
1.012\end{array}$ & $\begin{array}{c}(0.250) \\
0.935\end{array}$ \\
\hline Checkıng Account & $\begin{array}{c}(0.049) \\
0.728\end{array}$ & $\begin{array}{c}(0.064) \\
0.817\end{array}$ & $\begin{array}{c}(0.117) \\
1.163\end{array}$ & $\begin{array}{c}(0.118) \\
1.207\end{array}$ & $\begin{array}{c}(0.061) \\
0.722\end{array}$ & $\begin{array}{c}(0.078) \\
0.794\end{array}$ & $\begin{array}{c}(0.172) \\
1.623\end{array}$ & $\begin{array}{c}(0.170) \\
1.614\end{array}$ \\
\hline Stocks & $\begin{array}{c}(0.050) \\
0.700\end{array}$ & $\begin{array}{c}(0.066) \\
0.537\end{array}$ & $\begin{array}{c}(0.282) \\
1.342\end{array}$ & $\begin{array}{c}(0.283) \\
1.300\end{array}$ & $\begin{array}{c}(0.056) \\
0.678\end{array}$ & $\begin{array}{c}(0.069) \\
0.499\end{array}$ & $\begin{array}{c}(0.529) \\
1.251\end{array}$ & $\begin{array}{c}(0.529) \\
1.177\end{array}$ \\
\hline Credit Card Debt & $\begin{array}{c}(0.058) \\
1.061 \\
(0.053)\end{array}$ & $\begin{array}{c}(0.057) \\
0.943 \\
(0.063)\end{array}$ & $\begin{array}{c}(0.336) \\
0.771 \\
(0.098)\end{array}$ & $\begin{array}{c}(0.331) \\
0.759 \\
(0.097)\end{array}$ & $\begin{array}{c}(0.064) \\
1.160 \\
(0.068)\end{array}$ & $\begin{array}{c}(0.062) \\
0.964 \\
(0.072)\end{array}$ & $\begin{array}{c}(0.403) \\
0.920 \\
(0.183)\end{array}$ & $\begin{array}{c}(0.402) \\
0.867 \\
(0.194)\end{array}$ \\
\hline
\end{tabular}

Source: Survey of Income and Program Participation, 1996 - 2008 panels

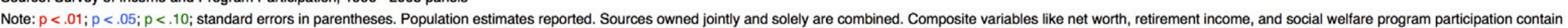

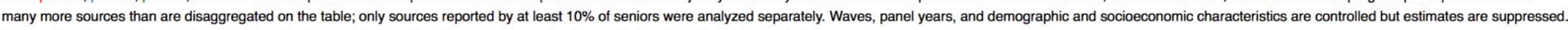
Only seniors that consistently lived or did not live in a multigenerational household over the time period are included in the analysis. 


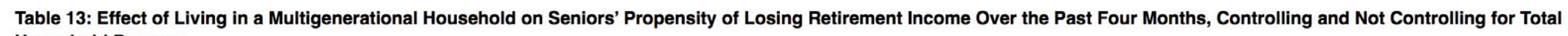
Household Persons

\begin{tabular}{|c|c|c|c|c|c|c|c|c|}
\hline \multirow{2}{*}{ Source } & \multicolumn{2}{|c|}{$\begin{array}{c}\text { Effect of Living in a Multigen } \\
\text { Household on Change in Source, } \\
\text { All Seniors }\end{array}$} & \multicolumn{2}{|c|}{$\begin{array}{l}\text { Effect of Living as a Non- } \\
\text { Household Head in a Multigen } \\
\text { Household on Change in Source, } \\
\text { Seniors in Multigen Households }\end{array}$} & \multicolumn{2}{|c|}{$\begin{array}{l}\text { Effect of Living in a Multigen } \\
\text { Household on Change in Source, } \\
\text { Household Head Seniors }\end{array}$} & \multicolumn{2}{|c|}{$\begin{array}{l}\text { Effect of Living in a Multigen } \\
\text { Household on Change in Source, } \\
\text { Non-Household Head Seniors }\end{array}$} \\
\hline & $\begin{array}{l}\text { Household } \\
\text { Persons Not } \\
\text { Controlled }\end{array}$ & $\begin{array}{l}\text { Household } \\
\text { Persons } \\
\text { Controlled }\end{array}$ & $\begin{array}{l}\text { Household } \\
\text { Persons Not } \\
\text { Controlled }\end{array}$ & $\begin{array}{l}\text { Household } \\
\text { Persons } \\
\text { Controlled }\end{array}$ & $\begin{array}{l}\text { Household } \\
\text { Persons Not } \\
\text { Controlled }\end{array}$ & $\begin{array}{l}\text { Household } \\
\text { Persons } \\
\text { Controlled }\end{array}$ & $\begin{array}{l}\text { Household } \\
\text { Persons Not } \\
\text { Controlled }\end{array}$ & $\begin{array}{l}\text { Household } \\
\text { Persons } \\
\text { Controlled }\end{array}$ \\
\hline \multirow{2}{*}{ Retirement Income } & 0.871 & 0.837 & 0.795 & 0.791 & 0.927 & 0.829 & 1.000 & 1.004 \\
\hline & $\begin{array}{c}(0.013) \\
1.012\end{array}$ & $\begin{array}{c}(0.017) \\
0.940\end{array}$ & $\begin{array}{c}(0.025) \\
0.896\end{array}$ & $\begin{array}{c}(0.025) \\
0.884\end{array}$ & $\begin{array}{c}(0.015) \\
1.035\end{array}$ & $\begin{array}{c}(0.019) \\
0.920\end{array}$ & $\begin{array}{c}(0.052) \\
1.073\end{array}$ & $\begin{array}{c}(0.059) \\
1.045\end{array}$ \\
\hline Social Security & $(0.022)$ & $(0.027)$ & $(0.032)$ & $(0.034)$ & $(0.025)$ & $(0.027)$ & $(0.077)$ & $(0.086)$ \\
\hline \multirow{2}{*}{ Retirement Income Excluding Social Security } & 0.807 & 0.810 & 0.703 & 0.718 & 0.887 & 0.801 & 1.0005 & 1.064 \\
\hline & $\begin{array}{c}(0.015) \\
0.735\end{array}$ & $\begin{array}{c}(0.021) \\
0.751\end{array}$ & $\begin{array}{c}(0.029) \\
0.632\end{array}$ & $\begin{array}{c}(0.029) \\
0.656\end{array}$ & $\begin{array}{c}(0.018) \\
0.827\end{array}$ & $\begin{array}{c}(0.022) \\
0.743\end{array}$ & $\begin{array}{c}(0.070) \\
0.956\end{array}$ & $\begin{array}{c}(0.083) \\
1.047\end{array}$ \\
\hline Interest Payments & $\begin{array}{c}(0.016) \\
0.996\end{array}$ & $\begin{array}{c}(0.022) \\
1.057\end{array}$ & $\begin{array}{c}(0.033) \\
0.786\end{array}$ & $\begin{array}{c}(0.034) \\
0.798\end{array}$ & $\begin{array}{c}(0.020) \\
1.061\end{array}$ & $\begin{array}{c}(0.023) \\
1.081\end{array}$ & $\begin{array}{c}(0.087) \\
0.971\end{array}$ & $\begin{array}{c}(0.106) \\
0.983\end{array}$ \\
\hline Pension & $(0.033)$ & $(0.051)$ & $(0.049)$ & $(0.053)$ & $(0.040)$ & $(0.059)$ & $(0.101)$ & $(0.108)$ \\
\hline
\end{tabular}

Source: Survey of Income and Program Participation, 1996 - 2008 panels

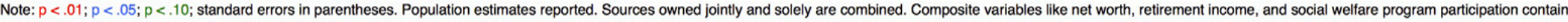

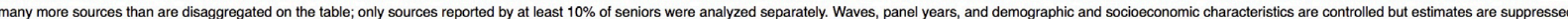
Only seniors that consistently lived or did not live in a multigenerational household over the time period are included in the analysis. 
Table 14: Effect of Living in a Multigenerational Household on Seniors' Propensity of Enrolling in a Social Welfare Program Over the Past Four Months, Controlling and Not Controlling for Total Household Persons

\begin{tabular}{|c|c|c|c|c|c|c|c|c|}
\hline \multirow{2}{*}{ Source } & \multicolumn{2}{|c|}{$\begin{array}{c}\text { Effect of Living in a Multigen } \\
\text { Household on Change in Source, } \\
\text { All Seniors }\end{array}$} & \multicolumn{2}{|c|}{$\begin{array}{l}\text { Effect of Living as a Non- } \\
\text { Household Head in a Multigen } \\
\text { Household on Change in Source, } \\
\text { Seniors in Multigen Households }\end{array}$} & \multicolumn{2}{|c|}{$\begin{array}{l}\text { Effect of Living in a Multigen } \\
\text { Household on Change in Source, } \\
\text { Household Head Seniors }\end{array}$} & \multicolumn{2}{|c|}{$\begin{array}{l}\text { Effect of Living in a Multigen } \\
\text { Household on Change in Source } \\
\text { Non-Household Head Seniors }\end{array}$} \\
\hline & $\begin{array}{l}\text { Household } \\
\text { Persons Not } \\
\text { Controlled }\end{array}$ & $\begin{array}{l}\text { Household } \\
\text { Persons } \\
\text { Controlled }\end{array}$ & $\begin{array}{l}\text { Household } \\
\text { Persons Not } \\
\text { Controlled }\end{array}$ & $\begin{array}{l}\text { Household } \\
\text { Persons } \\
\text { Controlled }\end{array}$ & $\begin{array}{l}\text { Household } \\
\text { Persons Not } \\
\text { Controlled }\end{array}$ & $\begin{array}{l}\text { Household } \\
\text { Persons } \\
\text { Controlled }\end{array}$ & $\begin{array}{l}\text { Household } \\
\text { Persons Not } \\
\text { Controlled }\end{array}$ & $\begin{array}{l}\text { Household } \\
\text { Persons } \\
\text { Controlled }\end{array}$ \\
\hline \multirow{2}{*}{ Social Welfare Program } & 1.777 & 1.202 & 2.529 & 2.301 & 1.255 & 1.010 & 1.746 & 1.343 \\
\hline & $\begin{array}{c}(0.129) \\
1.746\end{array}$ & $\begin{array}{c}(0.121) \\
1.297\end{array}$ & $\begin{array}{c}(0.327) \\
2.370\end{array}$ & $\begin{array}{c}(0.291) \\
2.188\end{array}$ & $\begin{array}{c}(0.119) \\
1.207\end{array}$ & $\begin{array}{c}(0.134) \\
1.089\end{array}$ & $\begin{array}{c}(0.420) \\
1.887\end{array}$ & $\begin{array}{c}(0.336) \\
1.489\end{array}$ \\
\hline Medicare & $(0.115)$ & $(0.121)$ & $(0.263)$ & $(0.238)$ & $(0.101)$ & $(0.130)$ & $(0.302)$ & $(0.267)$ \\
\hline \multirow{2}{*}{ Social Welfare Program Excluding Medicare } & 1.363 & 1.216 & 1.407 & 1.353 & 1.204 & 1.196 & 1.200 & 1.078 \\
\hline & $(0.054)$ & $(0.069)$ & $(0.108)$ & $(0.104)$ & $(0.056)$ & $(0.084)$ & $(0.162)$ & $(0.155)$ \\
\hline \multirow{2}{*}{ Medicaid } & 1.381 & 1.310 & 1.476 & 1.428 & 1.192 & 1.221 & 1.444 & 1.354 \\
\hline & $(0.062)$ & $(0.080)$ & $(0.108)$ & $(0.102)$ & $(0.060)$ & $(0.092)$ & $(0.200)$ & $(0.193)$ \\
\hline
\end{tabular}

Source: Survey of Income and Program Participation, 1996 - 2008 panels

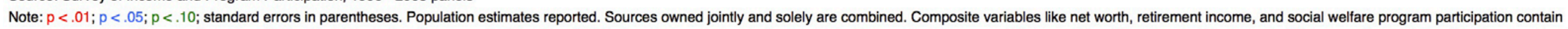

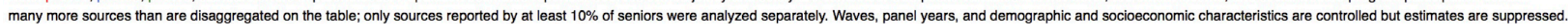
Only seniors that consistently lived or did not live in a multigenerational household over the time period are included in the analysis. 


\section{RECENT WORKING PAPERS FROM THE CENTER FOR RETIREMENT RESEARCH AT BOSTON COLLEGE}

How Does Student Debt Affect Early-Career Retirement Saving?

Matthew S. Rutledge, Geoffrey T. Sanzenbacher, and Francis M. Vitagliano, September 2016

The Labor Supply of Disabled Veterans: 1995-2014

Matthew S. Rutledge, Geoffrey T. Sanzenbacher, and Caroline V. Crawford, August 2016

The Mortality Effects of Retirement: Evidence from Social Security Eligibility at Age 62 Maria D. Fitzpatrick and Timothy J. Moore, August 2016

How Would Investing in Equities Have Affected the Social Security Trust Fund?

Gary Burtless, Anqi Chen, Wenliang Hou, Alicia H. Munnell, and Anthony Webb, July 2016

Are Early Claimers Making a Mistake?

Alicia H. Munnell, Geoffrey T. Sanzenbacher, Anthony Webb, and Christopher M. Gillis, July 2016

Marital Histories, Gender, and Financial Security in Late Mid-Life: Evidence from Four Cohorts in the Health and Retirement Study

Amelia Karraker and Cassandra Dorius, July 2016

Pension Participation, Wealth, and Income: 1992-2010

Alicia H. Munnell, Wenliang Hou, Anthony Webb, and Yinji Li, July 2016

The Interconnected Relationships of Health Insurance, Health, and Labor Market Outcomes

Matthew S. Rutledge, July 2016

Labor Force Dynamics in the Great Recession and Its Aftermath: Implications for Older Workers

Gary Burtless, July 2016

Elderly Poverty in the United States in the 21st Century: Exploring the Role of Assets in the Supplemental Poverty Measure

Christopher Wimer and Lucas Manfield, November 2015

The Economic Burden of Out-of-Pocket Medical Expenditures Before and After Implementation of the Medicare Prescription Drug Program

Ayse Akincigil and Karen Zurlo, November 2015

All working papers are available on the Center for Retirement Research website (http://crr.bc.edu) and can be requested by e-mail (crr@bc.edu) or phone (617-552-1762). 